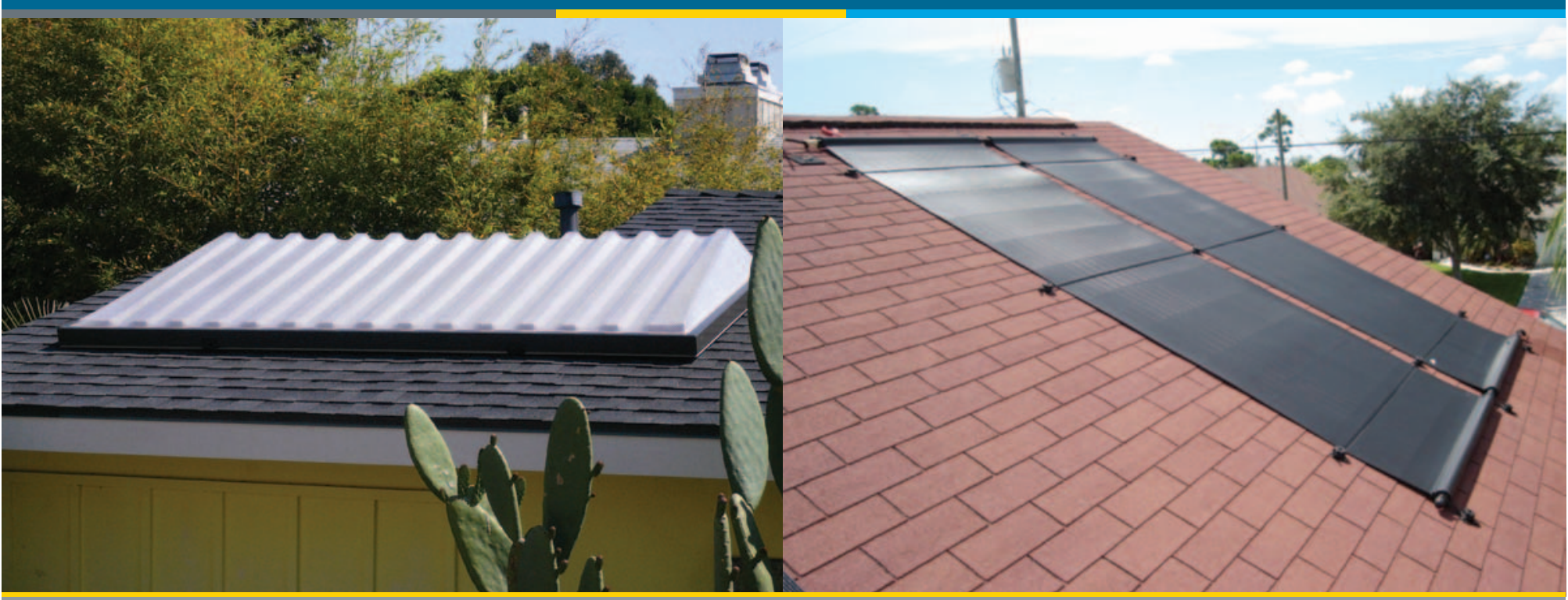

Two U.S.-manufactured low-cost plastic packaged systems are now available, including the SunCache system (above left) and the FAFCO system (above right). The manufacturers use plastic materials that reduce production and installation costs. Photos from Harpiris Energy and FAFCO

\title{
Solar Water Heating with Low-Cost Plastic Systems
}

Newly developed solar water heating technology can help Federal agencies more affordably meet the EISA requirements for solar water heating in new construction and major renovations.

Federal buildings consumed over 392,000 billion Btu of sitedelivered energy for buildings during FY 2007 at a total cost of $\$ 6.5$ billion. ${ }^{[1]}$ Earlier data indicate that about $10 \%$ of this is used to heat water.[2]

Targeting energy consumption in Federal buildings, the Energy Independence and Security Act of 2007 (EISA) requires new Federal buildings and major renovations to meet $30 \%$ of their hot water demand with solar energy, provided it is cost-effective over the life of the system. In October 2009, President Obama expanded the energy reduction and performance requirements of EISA and its subsequent regulations with his Executive Order 13514.

Federal facilities having financial difficulty meeting the EISA mandate and executive order (e.g., facilities with natural gas) can take advantage of two low-cost plastic packaged solar water heating systems, recently developed under a collaboration between industry and the U.S. Department of Energy (DOE). These systems, which are the focus of this document, typically have lower performance than conventional solar water heating designs. At lower solar fractions* and operating temperatures, however, performance

* Lower solar fractions mean "at a lower fraction of required water heating energy provided by solar energy. The remaining fraction is provided by conventional gas or electricity. is reasonably comparable, and these systems are capable of meeting the statutory requirements of $30 \%$ solar power efficiently and cost-effectively.

\section{Overcoming the Cost Barrier}

Benefits and applications of solar water heating are wellknown, and have been covered in many publications found in the references. However, the single biggest market barrier for solar water heaters is cost. For single-family systems with national-average water draw, paybacks with conventional solar water heaters often exceed expected system life of 20 to 30 years, as shown in Fig. i (map b). However, the picture changes dramatically when Federal tax credits and state and utility incentives are considered, with paybacks as low as five years from the Federal tax credit alone. Federal agencies should strongly consider partnering with private sector developers through alternative financing mechanisms to lower the delivered cost of solar hot water.

The new low-cost plastic solar water heating systems can help Federal facilities meet the EISA 2007 mandate and subsequent executive orders while still providing a reliable and affordable means for reducing costs and pollution. The manufacturers of the low-cost systems have reduced costs by replacing many system materials with plastic, while 
(a)

Electricity Rate for Savings-to-Investment Ratio = 1 for Solar Hot Water Systems (Elec) (Not Considering Incentives)

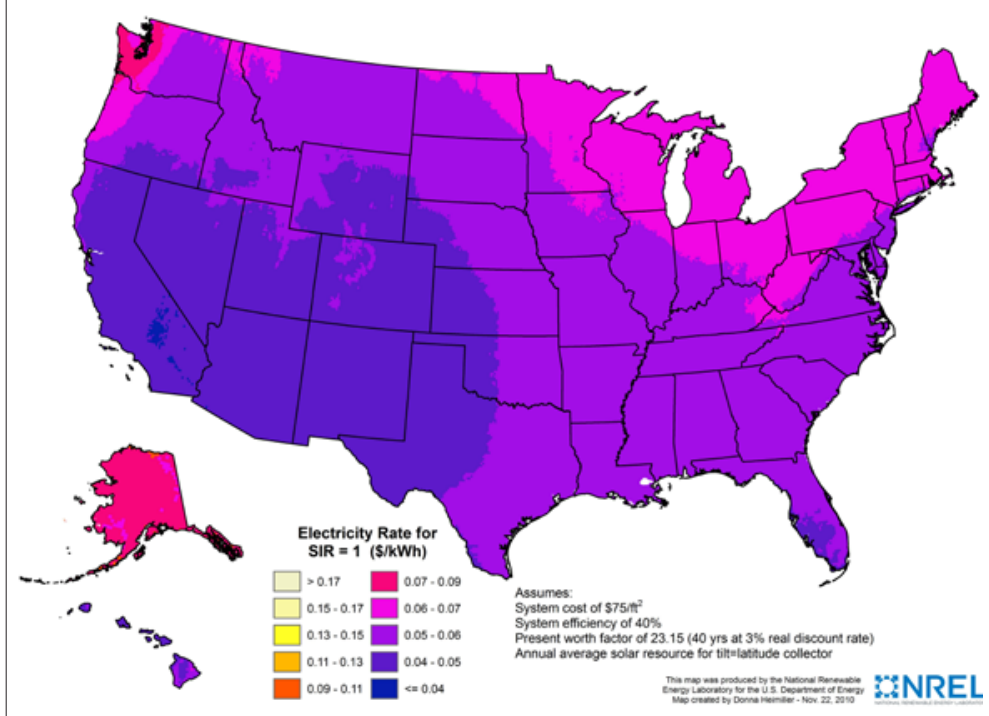

(b)

Electricity Rate for Savings-to-Investment Ratio $=1$ for Solar Hot Water Systems (Elec) (Not Considering Incentives)

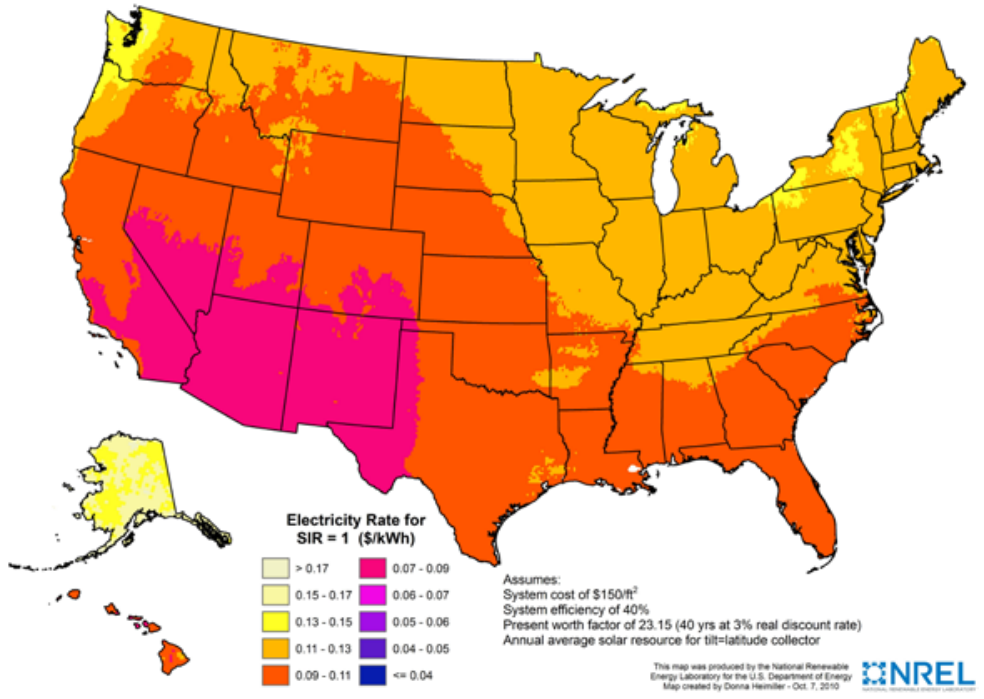

Fig. i, a shows cost of delivered energy for a conventional system at $\$ 75 / \mathrm{ft}^{2}$ and Fig. i,b shows the cost of delivered energy for a low cost system at $\$ 150 / \mathrm{ft}^{2}$ assuming that all other parameters are the same. The conventional system and the low-cost system have the same performance only when meeting a small fraction of the overall hot water use. Illustrations by Donna Heimiller, NREL

keeping potable water in conventional plumbing and tanks. In addition, the plastic systems are lighter and use PEX* supply-return piping. They will thus install more quickly than conventional metal-glass systems with heavy collectors and copper piping. These systems are usually cheaper than conventional solar water heating systems and usually have lower installation costs, although other market factors (such as the distribution channels) can result in these systems costing the same as conventional systems. To protect the commodity polymer materials, the units are designed so that stagnation does not produce damaging high temperatures; this avoids overheat damage. As with conventional collectors, multiple polymer collectors of either type can be ganged in parallel to form larger arrays suitable for commercial or industrial applications with larger loads.

Costs for complete installed solar hot water systems vary widely, from as low as $\$ 10 / \mathrm{ft}^{2}$ for large-pool systems with unglazed plastic collectors to $\$ 250 / \mathrm{ft}^{2}$ for small residentialscale systems, depending on the market scenario (retrofit vs. new construction, inexperienced firms with low-volume installations that bid high, etc.). The pre-rebate cost in the recent California Solar Initiative trial program was $\$ 168 / \mathrm{ft}^{2}$, averaging over 275 residential systems with areas less than $48 \mathrm{ft}^{2}[3]$. In this publication, $\$ 150 / \mathrm{ft}^{2}$ is considered to be typical of conventional solar water heating systems and $\$ 75 / \mathrm{ft}^{2}$ is considered typical of the low-cost plastic systems.

* Cross-linked Poly-Ethylene, a type of plastic that has been processed to strenghten it and increase its durability.
The two systems highlighted in this document, FAFCO and SunCache, were developed as part of a DOE program to lower costs of solar water heating systems. For single-family homes, DOE's goal for the pre-rebate cost of installation of the packaged systems was to reduce the levelized cost of energy (LCOE) by at least 50\%. In larger systems, appropriate for multi-family, commercial, and industrial installations, costs are comparatively even lower for systems with plastic collectors than for systems with more expensive conventional collectors because collector area for large systems is a significantly larger fraction of system cost vs. the small single-family systems. However, to prevent overheating issues, these systems omit collector glazing and/or insulation, which reduce performance, depending on the operating temperature range.

The use of plastic materials for heating potable water is new to the market. The system designs are novel in some respects and field feedback is limited. Therefore, there is a higher risk for developing problems with these new systems than with timetested metal-glass technology systems. The risk is tempered by the fact that plastic collectors by the supplier FAFCO have been used in similarly unpressurized pool heating systems reliably for many years, with lifetimes far greater than 25 years. Systems by SunCache have been tested in stagnation (left in the sun with no water flowing through them to reach the maximum possible temperature) in Phoenix for two years, and the supplier also has six years of reliable field experience with initial installations. In any case, it appears that additional risk is quite modest. 


\section{Resources}

The organizations below provide design assistance and system certification verification, as well as supplier and tax incentive information to Federal facilities.

\section{Andy Walker}

National Renewable Energy Laboratory

Phone: 303-384-7531

Email: andy.walker@nrel.gov

Database of State Incentives for Renewable Energy

www.dsireusa.org

Solar Rating and Certification Corporation

www.solar-rating.org

Solar Energy Industries Association

www.seia.org

\section{References}

[1] Annual Report to Congress on Federal Government Energy Management and Conservation Programs. Federal Energy Management Program. Fiscal Year 2007. Available at: www.eere.energy.gov/femp/pdfs/annrep07.pdf.

[2] Buildings Energy Data Book: 4.2 Federal Buildings and Facilities Characteristics September 2008. U.S. Department of Energy. March 2009. Available at: buildingsdatabook.eere. energy.gov/docs\%5CDataBooks\%5C2008_BEDB_ Updated.pdf

[3] California Solar Initiative-Thermal Program (Solar Water heating). Available at: www.pge.com/csithermal/ 


\section{Contents}

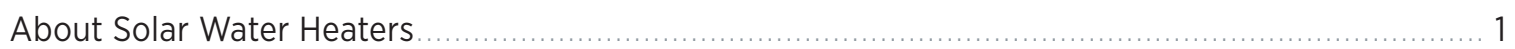

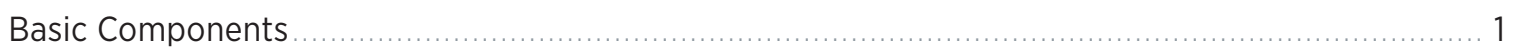

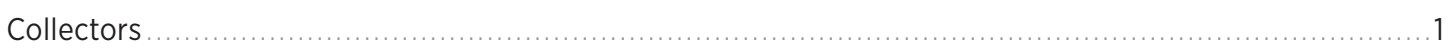

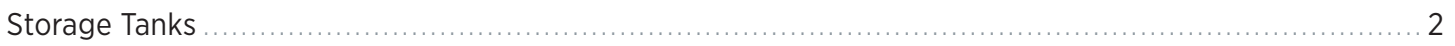

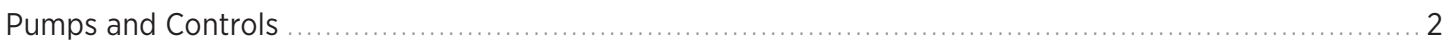

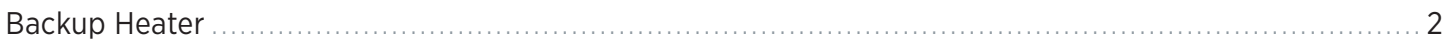

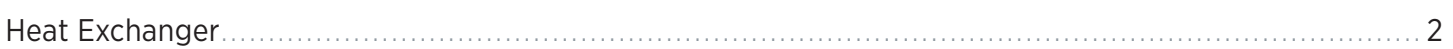

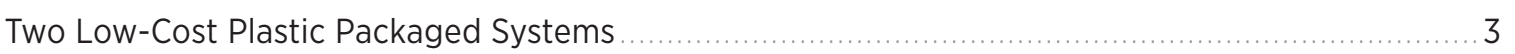

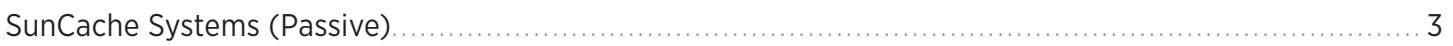

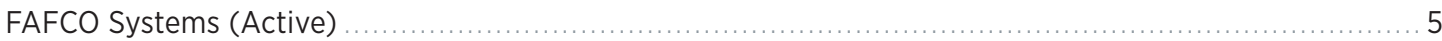

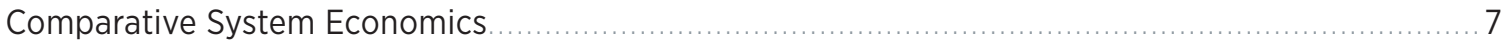

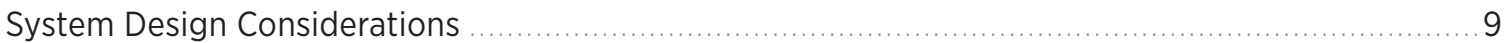

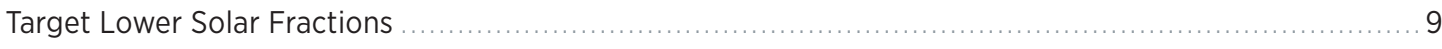

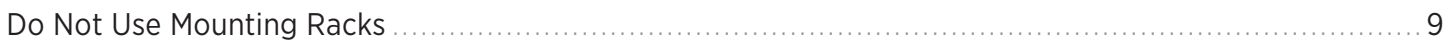

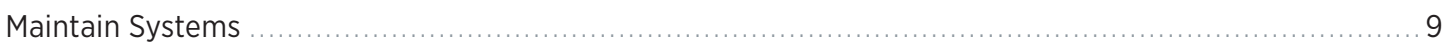

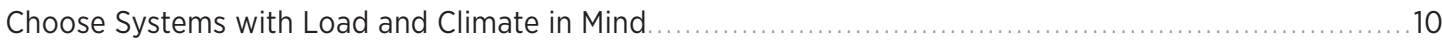

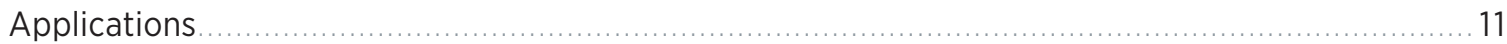

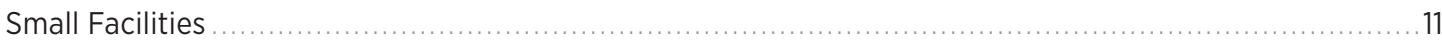

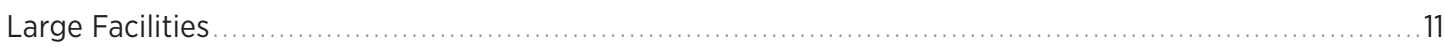

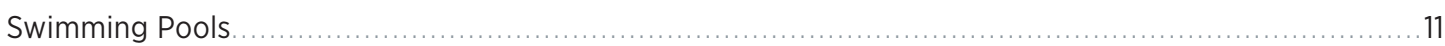

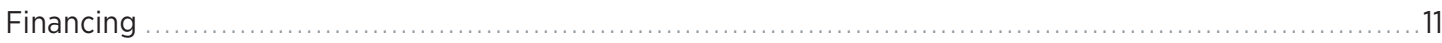

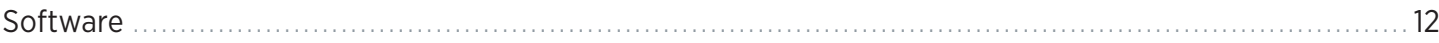

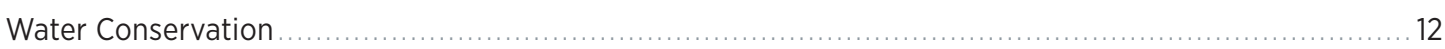

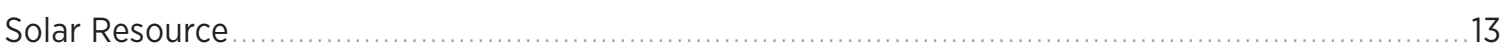

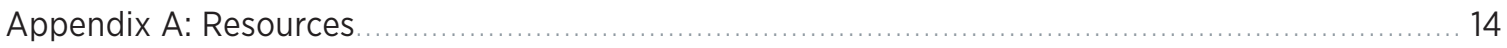

Appendix B: SRCC OG300 Rating for SunCache and FAFCO 


\section{About Solar Water Heaters}

Heating water with solar energy can be a cost effective and environmentally responsible way to generate hot water, minimizing the expense of electricity or fossil fuels to heat water and reducing the associated environmental impacts. Solar water heating systems use solar collectors to capture sunlight to heat water (or an antifreeze liquid) that is then moved from the collector to storage and then to its point of use. There are two types of systems, active and passive. Active systems use electricity for pumping the fluid and have a reservoir or tank for heat storage and subsequent use. Passive systems rely on natural convection and water pressure during draw to move fluids, and require no circulation hardware. The systems may be used to heat water in homes, businesses, and for industrial uses. In many climates, a solar hot water system can provide up to $80 \%$ or more of the energy needed to heat water. Solar water heating systems almost always require a backup system for cloudy days and times of increased demand. Conventional natural gas or electric water heaters typically provide backup, so hot water is always available, regardless of the weather.

\section{Basic Components}

There are many good introductions to solar thermal technology, and some are given in the references. In this section, some common components are discussed briefly to make clear how the plastic systems differ from conventional systems.

\section{Collectors}

There are primarily three types of solar collectors used for common solar water heating systems: flat plate, integral collector storage (ICS), and evacuated tube. A fourth type is parabolic trough, but these collectors are only used to heat water for very large facilities or for high-temperature applications. Conventional flat-plate collectors are insulated boxes with glass covers that contain a dark thin copper plate used to absorb the sun's heat underneath. The collector housing is typically steel or aluminum. Unglazed collectors are typically used for heating pools and house a dark absorber plate (metal or plastic) without a cover. Unglazed collectors for domestic hot water have recently been introduced as low-cost alternatives to conventional glass and metal collectors, as in the FAFCO system described in the next section. Conventional integral collector-storage collectors use large-diameter coated copper tubes or tanks in an insulated, glazed box. Evacuated-tube solar collectors use transparent glass tubes that contain a metal absorber tube attached to a fin. Most collectors sold in the U.S. today are flat plate collectors, constituting over $90 \%$ of the market.

Flat plate collectors are most often constructed of copper piping, aluminum frames, and tempered glass covers. Low-cost plastic packaged solar water heating systems, on the other hand, use commodity polymer materials to form the collector. There are few glazed polymer collectors on the market today because of the overheating issue.

\section{Integrated Collector Storage}

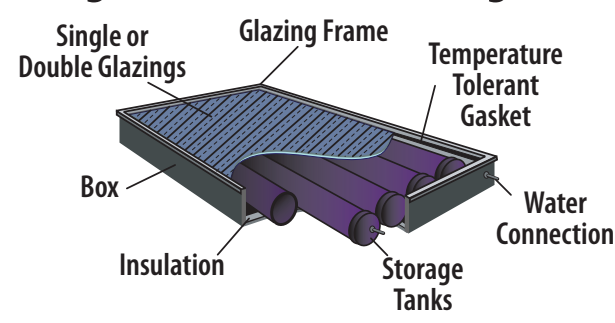

\section{Evacuated Tubes}

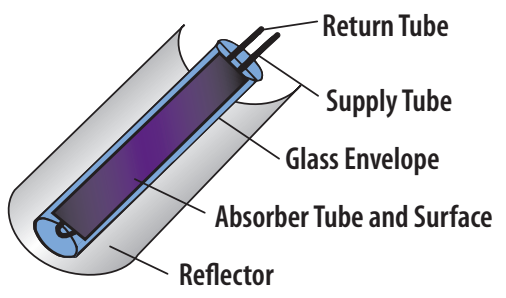

\section{Flat Plate Collector}
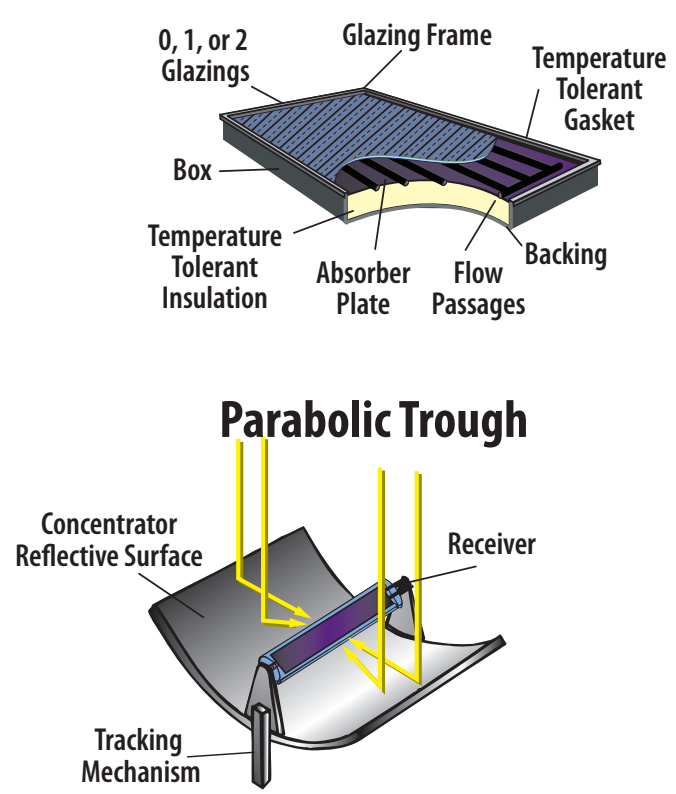

Fig. 1. Four types of collectors: batch, flat plate, evacuated tube, and parabolic tough. Illustration by Jim Leyshon, NREL 
High temperatures in conventional glazed collectors reach $250^{\circ} \mathrm{F}$ to $400^{\circ} \mathrm{F}$ if flow through them is interrupted on clear warm days (called stagnation). Heat transfer fluid trapped in these collectors experiences accelerated degradation, which can form acid and deteriorate system components. Typical commodity plastics, which are used in these novel plastic systems, cannot withstand these temperatures. In pursuit of system designs that enable low cost plastics, the overheat issue has been designed out. This problem is entirely avoided in the FAFCO systems by omitting the glazing, which leads to maximum temperatures around $100^{\circ} \mathrm{C}$, well below the maximum temperature of the polymer material. On the other hand, the SunCache ICS system from Harpiris Energy (Harpiris), described in the next section, is glazed. It consists of a rotomolded plastic ICS with a plastic cover, and omits insulation to keep stagnation temperatures down. Stagnation temperatures over two summers in Phoenix, AZ reached a maximum of $185^{\circ} \mathrm{F}$ for a few hours in August.

\section{Storage Tanks}

Storage is generally required to couple the timing of the intermittent solar resource with the timing of the hot water load. In general, one to two gallons of storage water per square foot of collector area is adequate. Storage can either be potable water or non-potable water if a code-approved load side heat exchanger is used. For conventional small systems, storage is most often in the form of glass-lined steel tanks at line pressure. For large systems, unpressurized storage tanks made of polymers or using polymer liners are common. This approach can reduce storage cost per unit volume considerably compared to small pressurized tanks.

In the FAFCO system, conventional glass-lined pressure tanks are used. The recommended system uses a separate solar tank (essential for gas). Using a single tank is generally not recommended unless a careful study of performance and water demand shows the system can provide adequate hot water supplies that won't generate user complaints. In that mode during cloudy periods, occupants have typically less than one third the capacity of the tank with both elements and will frequently run out of hot water in such conditions. In the SunCache system, a thin-wall, unpressurized plastic tank reduces the cost relative to the large copper tubes in conventional ICS. Dry unit weight of conventional ICS systems is about $300 \mathrm{lbs}$ vs. about $75 \mathrm{lbs}$ for the SunCache.

\section{Pumps and Controls}

Active systems have pumps and use either a differential controller to start and stop the pumps based on the temperature difference between collector and tank, or a PV-driven pump that provides driving voltage only when the sun shines and energy is to be collected. The FAFCO system is an active system, and it has a compact flat-plate heat exchanger external to the tank. A differential controller is used, powered by either AC power or a PV cell. Conventional ICS and thermosiphon passive systems do not have pumps or controllers, but rely on natural convection and water pressure during draw to move water. The SunCache system is passive, with no electronics or wiring needed.

\section{Backup Heater}

Most solar water heaters sold today require a backup heater to meet $100 \%$ of the instantaneous peak hot water demand on cloudy days or when the solar system output is insufficient. Conventional systems are most often sized to meet $60 \%$ to $80 \%$ of the water-heating load, covering most of the load during summer, when temperatures are high and water use lower, but leaving the system unable to meet all of the winter load. Low-cost plastic solar water heating systems of the same size as a conventional system will usually be targeted to offset a lower fraction of the hot water energy, because they have less insulation and more heat loss than conventional systems. Thus, as the water heats up, the low-cost collectors become less efficient and meet the total load fewer days of the year, especially in cold climates. On the other hand, the plastic systems perform better than conventional systems at lower water temperatures. Because there are no glazing reflection losses, the FAFCO unglazed system can be more efficient than glazed ones at low water temperatures. Thus, with these low-cost plastic systems, it is most cost effective in larger systems to target lower solar fractions with lower operating temperatures.

\section{Heat Exchanger}

A heat exchanger transfers heat from the heat-transfer fluid in the solar loop (usually either water or a water-glycol antifreeze mixture) to the pressurized water. There are almost as many heat exchanger designs as there are systems. The heat exchanger can be external or internal to the tank, and can take many forms. Examples are a series of copper coils submerged in the water storage tank or a counterflow shell-in-tube heat exchanger outside of the storage tank. In the FAFCO system, the heat exchanger is a compact external plate-frame heat exchanger made of brass and steel. In the SunCache system, the heat exchanger is a copper serpentine coil immersed in the top one third of the unpressurized storage tank. 


\section{Two Low-Cost Plastic Packaged Systems}

Two low-cost plastic packaged systems have been recently introduced to the American market. The SunCache is an unpressurized ICS collector, with an immersed load-side heat exchanger. The FAFCO 200 Series is a conventional drainback system with unglazed plastic collectors, pressurized storage, and an external heat exchanger. A more detailed description of these systems follows.

\section{SunCache Systems (Passive)}

SunCache is a low-cost residential and commercial solar water heating system designed for use in warm climates, such as the U.S. Sunbelt and tropical climates generally. SunCache is a passive system with the storage tank integrated into the collector. It has no moving parts, uses no

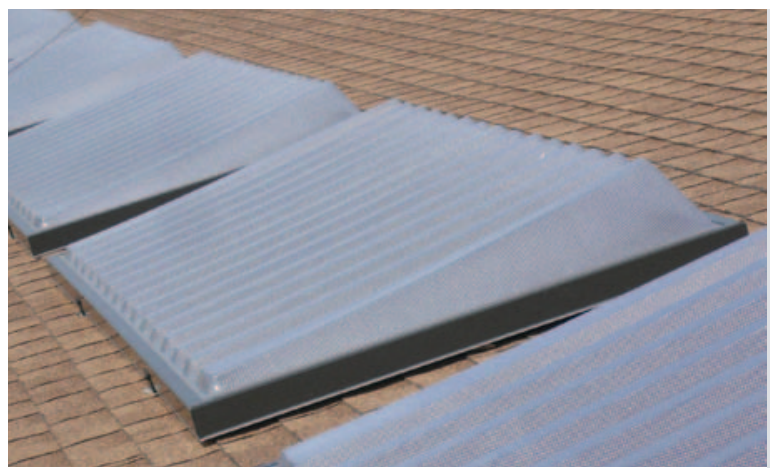

Fig. 2. For this project at a mid-rise apartment building in Sacramento, California, Harpiris installed 65 collectors across 35 separate systems, ranging from one or two collector systems pre-heating individual tankless gas water heaters, to up to eight collector arrays pre-heating pairs of 100 gallon water heaters. Federal and utility incentives paid for more than $60 \%$ of the total system cost. (Top) Eight SunCache collectors in parallel, feeding 200 gallon storage. (Bottom) Individual collectors installed on individual units with tankless water heaters. Photos from Harpiris Energy
- Preheats water entering either electric storage, gas storage, or gas tankless water heaters

- Tested to exceed 30 PSF uplift, equivalent to a basic wind speed of $110 \mathrm{MPH}$

- OG-300 certified by SRCC (Solar Rating and Certification Corporation)

NOT SHOWN:

- Pre-assembled valve package with all required plumbing components (except tempering valve)

- Stainless steel quick-install mounting brackets

- Includes all required fasteners (stainless steel)

- Steel drill templates make locating holes easy

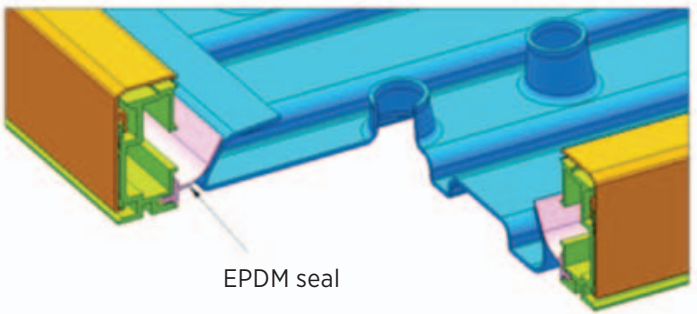

Thermoformed impact-modified acrylic glazing is not affected by UV

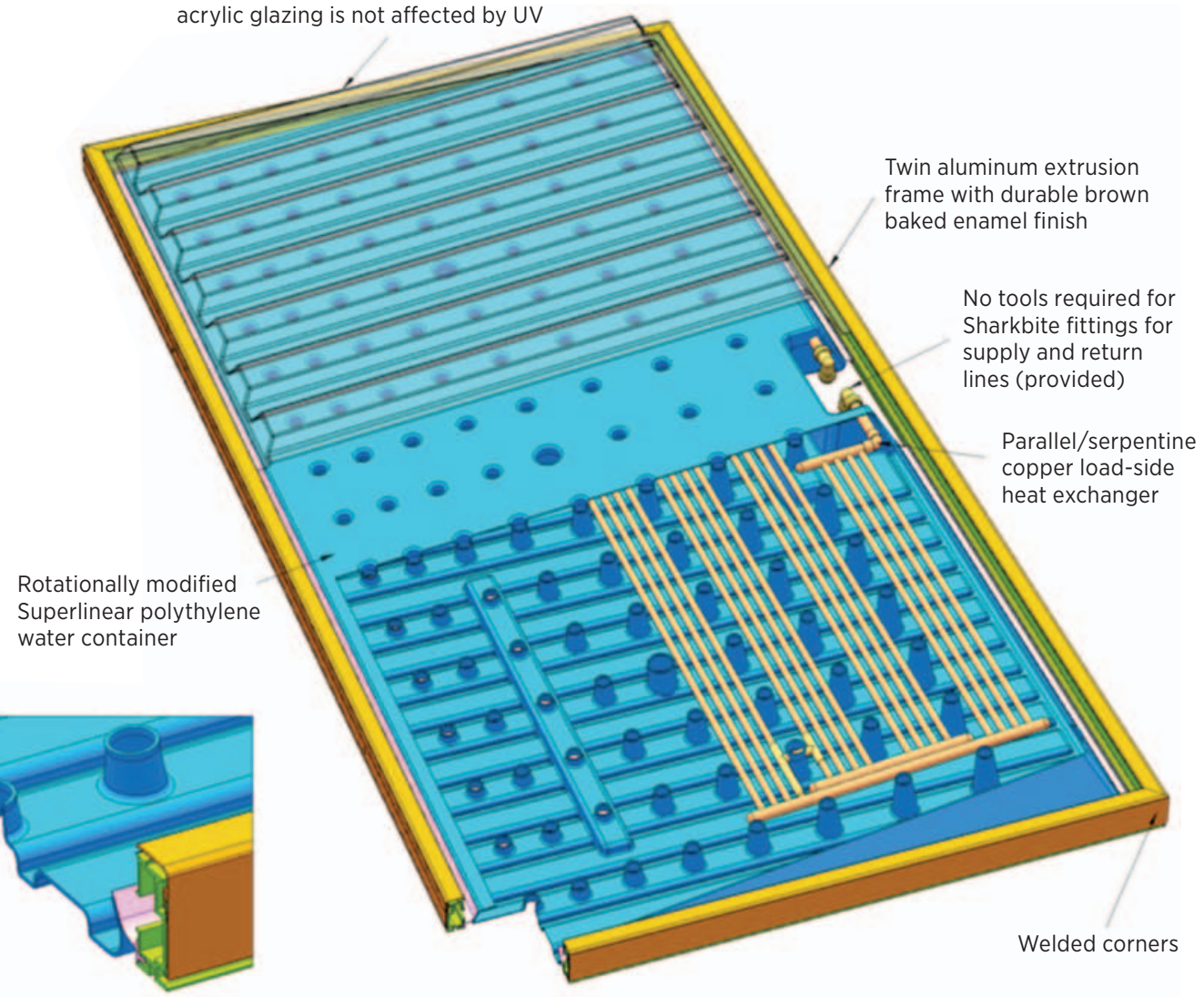

Fig. 3. Schematic of the glazed SunCache collector. The holes in the absorber are from the standoffs holding the top absorber surface in place against hydrostatic pressure. Illustration from Harpiris Energy 
electricity, and doesn't need the pumps, sensors, or controllers that active solar water heating systems require. The low cost is accomplished by the extensive use of plastic materials, which replace the metal- and glass-made collector and glazing used in conventional systems. The system uses expensive copper just where it is most effective and its strength and safety are needed: in the heat exchanger. The system cannot achieve temperatures above $185^{\circ} \mathrm{F}$ (as seen in summer stagnation tests in Phoenix, AZ), so PEX piping is allowed for supply/ return piping. PEX is much easier and quicker to install than sweated copper piping, reducing installation cost significantly. No soldering is needed. Because the system is lightweight, no cranes are needed for installation, further reducing costs. For residential applications, systems with one or two

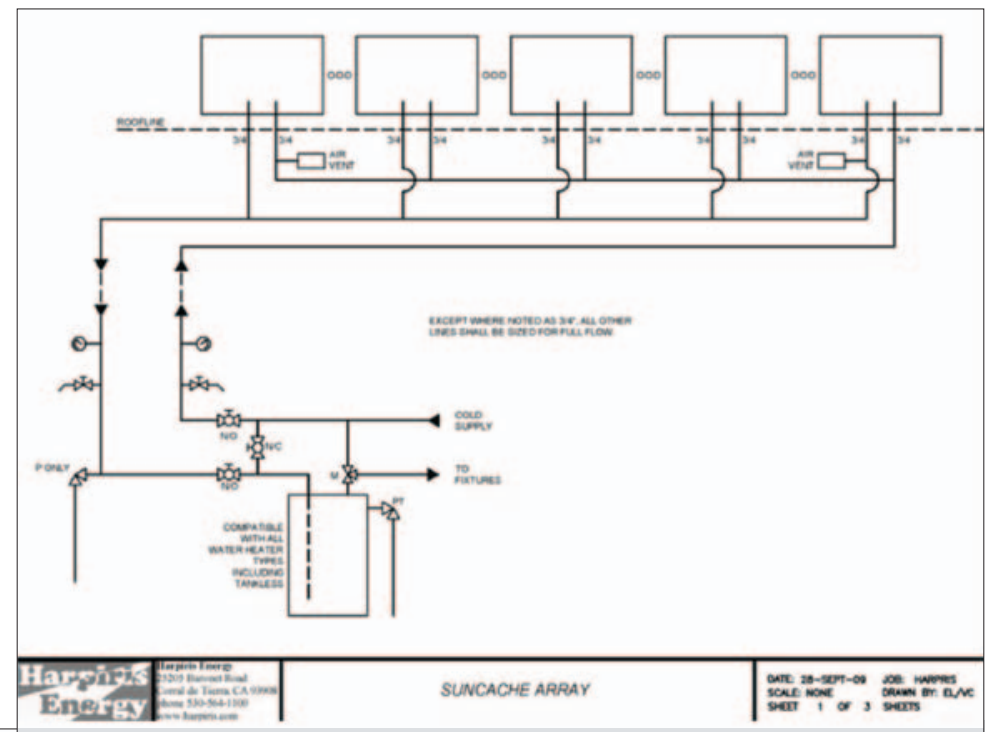

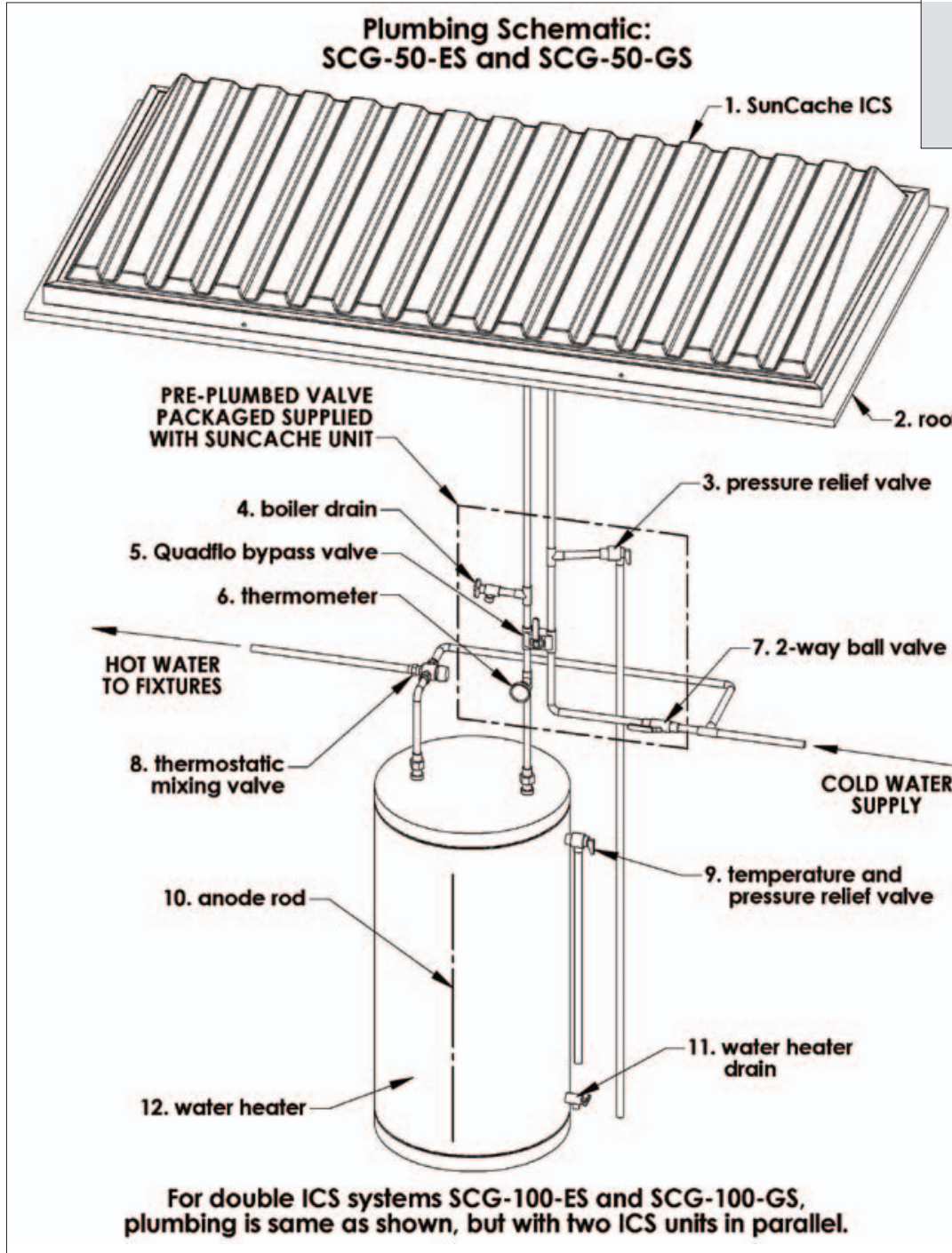

Fig. 4. Schematic system diagram for the SunCache solar water heater. Note that the parts enclosed in the dotted lines come in a factoryassembled unit. SunCache is compatible with all conventional water heaters. SunCache can be used in both single-family and multi-family/ commercial installations. I/lustration from SunCache
Fig. 5. System schematic for a multi-family installation with the SunCache collectors. The collectors are basically plumbed in parallel. Illustration from Suncache

SunCache collectors typically reduce water heating energy use by $30 \%$ to $70 \%$ depending on location, household size, and usage pattern. SunCache can also be used in commercial applications. In these cases, economics improves as the balance of system costs and installation costs reduce per unit area, compared to single-family systems generally.

The SunCache system comes with a 10-year warranty, matching the industry standard for collectors. But unlike other collectors, SunCache is delivered as an all-in-one system, and the entire solar water heating system is covered by a 10 -year warranty that includes freeze damage in approved installation areas. SunCache has been OG-300 certified by the Solar Rating and Certification Corporation (SRCC), qualifying it for the $30 \%$ Federal tax credit. (See Appendix B: SRCC OG300 Rating). It has also been certified by the Florida Solar Energy Center (FSEC). Based on tests underway at the National Renewable Energy Laboratory (NREL), SunCache can survive $-14^{\circ} \mathrm{C}$ for 18 hours, and appears to have better freeze tolerance than conventional coppertube ICS. Modeling and test results for freezing of the SunCache will be published in 2011, including maps of where it is safe to install the unit with PEX piping. For now, the Pipe Freeze Prevention for Passive Solar Water Heaters Using a Room-Air Natural Convection Loop published by NREL can be used as conservative guidance on where it is safe to install these systems (See Appendix A: Resources). A map of freeze probabilities based upon copper pipe 


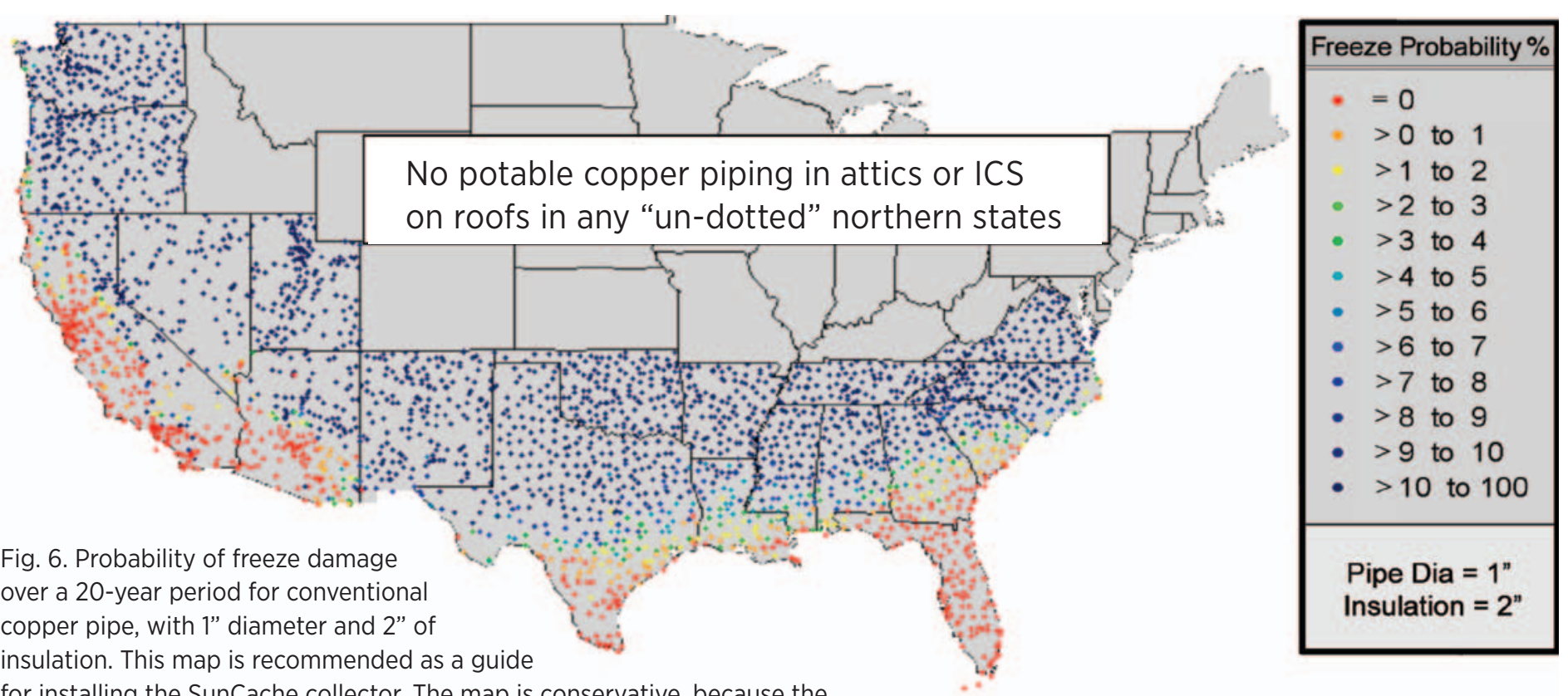

for installing the SunCache collector. The map is conservative, because the SunCache uses PEX pipe (which will not burst on freezing solid) as supply/return,

and removes the copper heat exchanger from contact with ambient air (which delays the onset of freezing). I/lustration by Jay Burch, NREL

freezing is shown in Fig. 6; it is certainly safe in regions with zero freeze probability. It is expected that the safe region will expand from this map, because of the use of PEX supply/ return piping (which is very freeze-tolerant) and a design that keeps the heat exchanger from direct contact with the ambient air. However, until that study is complete, it is best to be conservative and use the freeze map.

SunCache is sold by Harpiris, a 2008 startup firm created to commercialize the technology. The technology was developed by Davis Energy Group with support from DOE and NREL.

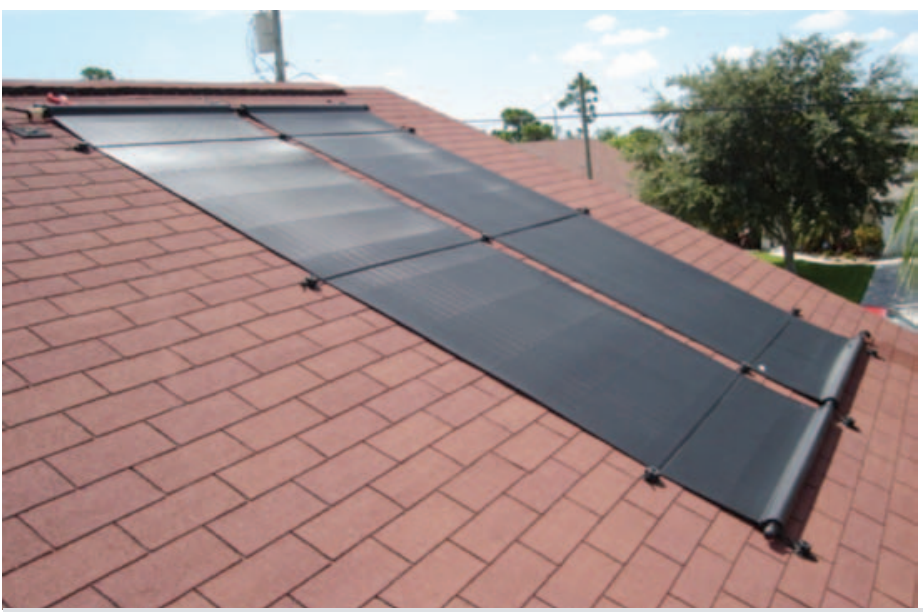

\section{FAFCO 200 Series and $\mathbf{5 0 0}$ Series Systems (Active)}

FAFCO has developed two low-cost solar water heater models: FAFCO 200 Series and FAFCO 500 Series.

The FAFCO 200 Series is a drainback design, as shown schematically in Fig. 8. It was released in January 2007. The FAFCO 500 Series is a glycol system design, as shown schematically in Fig. 9. Both models use FAFCO's unglazed collector, made from a polypropylene copolymer with proprietary additives for resisting UV and oxidation. Collectors in the field have stayed in operation 25 years.

Fig. 7. FAFCO solar water heating systems can be rolled-out onto the roof during installation. The systems are freeze tolerant, do not overheat, and can be used virtually anywhere in the United States. With unglazed collectors such as these, winter performance will be low or non-existent in cold and windy climates. A two-panel drainback system (FAFCO Series 200, shown on the left), providing $48 \mathrm{ft}^{2}$ of collector or, (right) A four-panel drainback system, providing $96 \mathrm{ft}^{2}$ of collector area. Both systems have a very low profile compared to conventional collectors. Photos from FAFCO 


\section{How It Works}

(1)

The FAFCO polymer solar collectors channel

water and absorb solar heat from the sun.

2

Set the controller to automatically operate the system during the day when there is enough solar energy to heat your water.

(3) The circulation module transfers the heat from the solar collectors to your hot water tank.

(4) The solar heated water in your hot water tank is available for all of your existing hot water needs including clothes washing, kitchen uses such as dish washing and sink, and bath uses such as shower, bath and bathroom sinks.

When not in operation, the water in the solar collectors drain back to the wall mounted drain back tank to prevent any chance for the water to freeze.

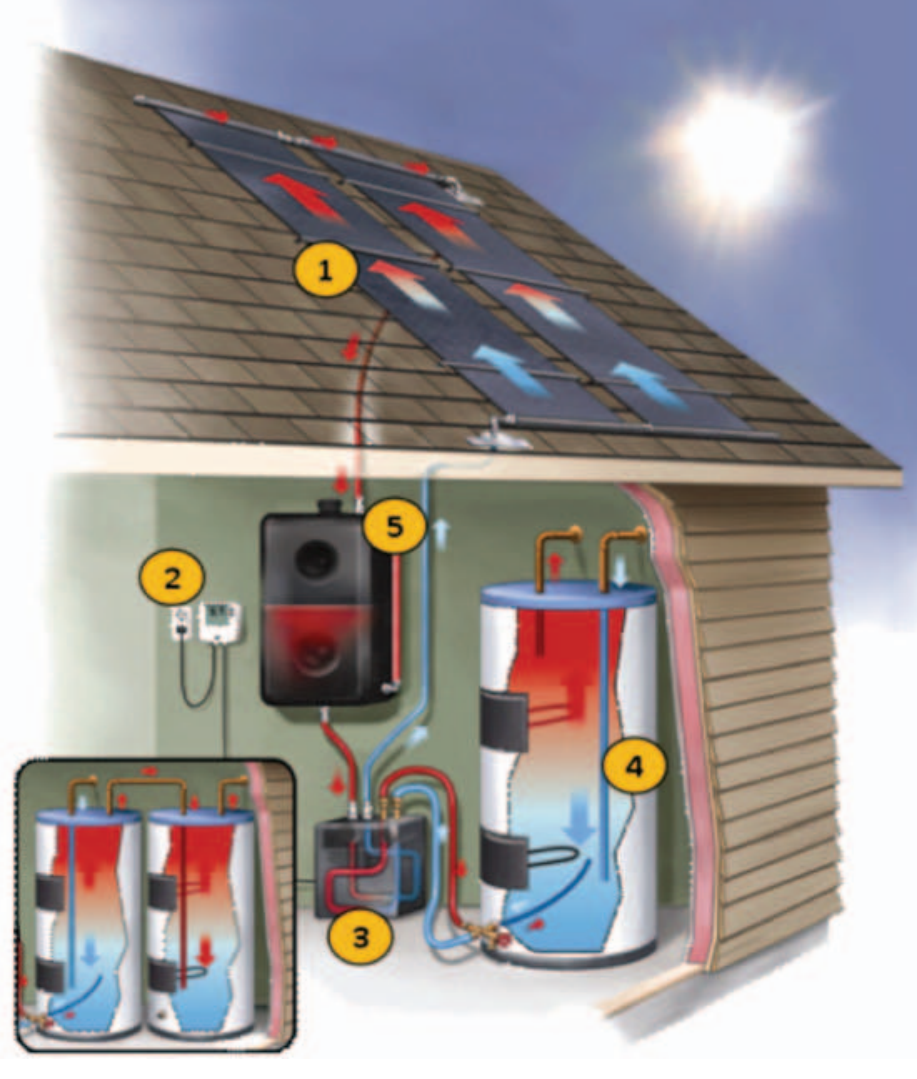

Fig. 8. Schematic diagram of the FAFCO Series 200 drainback solar water heater. Illustration from FAFCO

1) Highly efficient solar collectors absorb heat from the sun.

2 The solar heat is delivered to a module located on the side of the water heater.

3 Cold filtered water is circulated through the module where it is heated by the solar energy and delivered to the water heater.

4 Solar heated water is available for bath, showers, clothes washer, dishwasher, and other hot water fixtures.

5 An expansion receiver holds heat transfer fluid and keeps system pressures low.

6 An optional PV solar panel is available that enables operation even during a power outage.

(7) Dual tank systems have a separate solar storage tank for additional capacity and are necessary for gas water heaters.

Fig. 9. Schematic diagram of the FAFCO Series 500 glycol solar water heater, shown with the PV option. Illustration from FAFCO

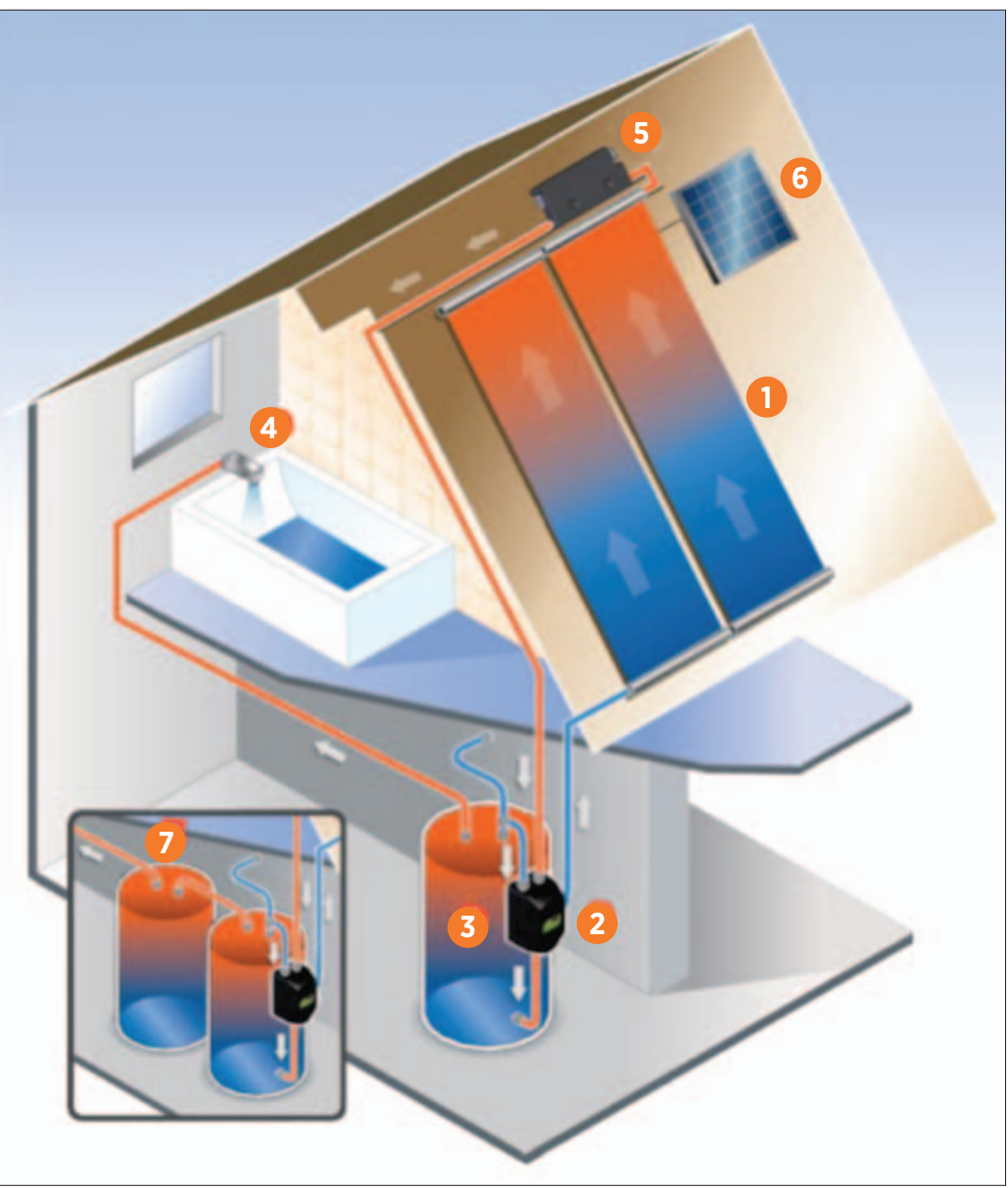




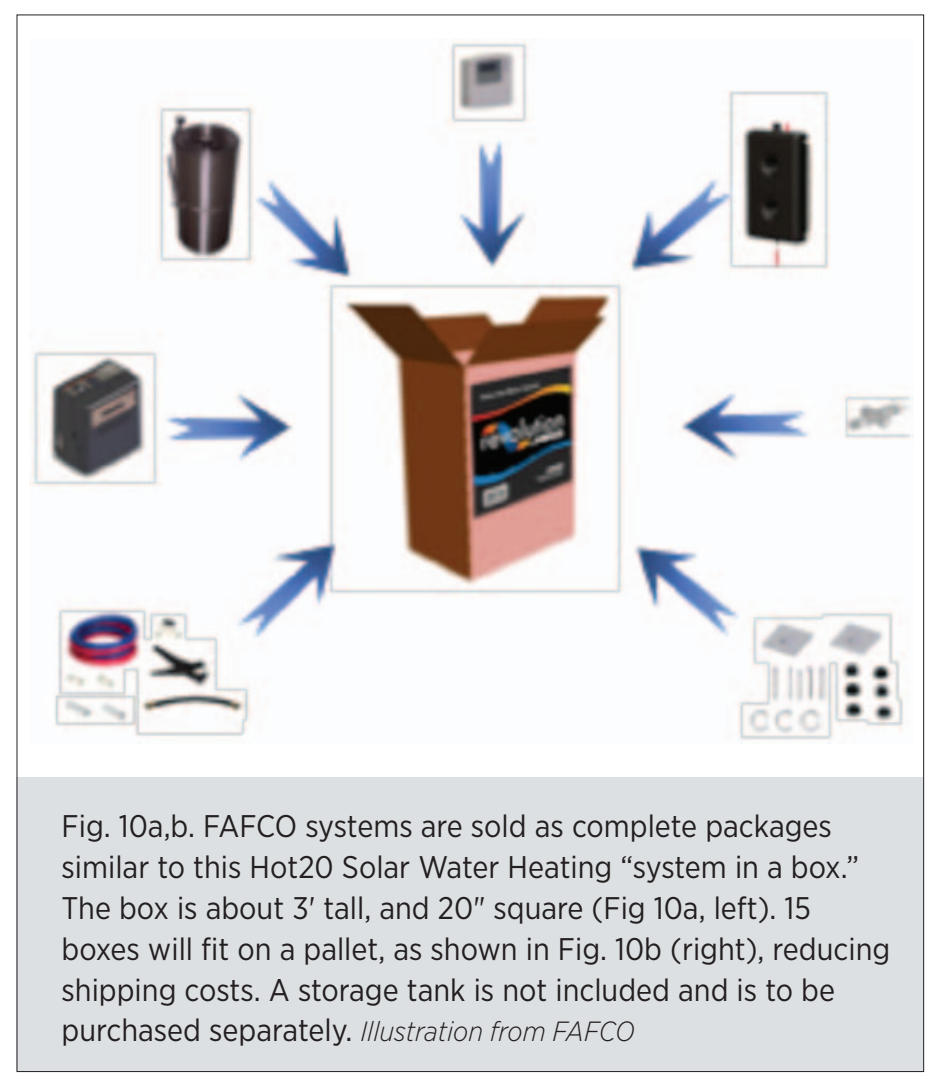

The flexible, light-weight collectors install quickly, as is the case with pool collectors. The systems can scale up in area in increments of $48 \mathrm{ft}^{2}$. Both systems are freeze-protected by virtue of their designs. The system has a DC controller and DC pump, which can be powered by AC through an AC/DC convertor, by a PV cell, or by both (the AC/DC convertor is shut down when PV power is adequate). Systems come with a 10-year warranty and are certified by the SRCC, qualifying it for the 30\% Federal tax credit. One novel feature about these systems is that for single-family/residential applications, everything is included in one box: the solar collectors, pumping module, control, and drainback tank in the 200 Series case. A complete FAFCO 200 Series system is shown in Fig. 10a,b; the small size/weight reduces shipping costs.

The FAFCO 200 Series water heater is an active drainback system, as shown schematically in Figure 8. When solar energy becomes unavailable or when heated water is not required, the system turns off automatically and all water "gravity drains" down into the drainback tank so the water cannot freeze on the roof or in an attic. There are two electric pumps in the circulation module that circulate water to the solar collectors from the heat exchanger, and water from the heat exchanger to the water heater.

The FAFCO 500 Series water heater is an active glycol system, shown schematically in Figure 9. The glycol solution (which won’t freeze until $-40^{\circ} \mathrm{F}$ ) stays in the collector loop

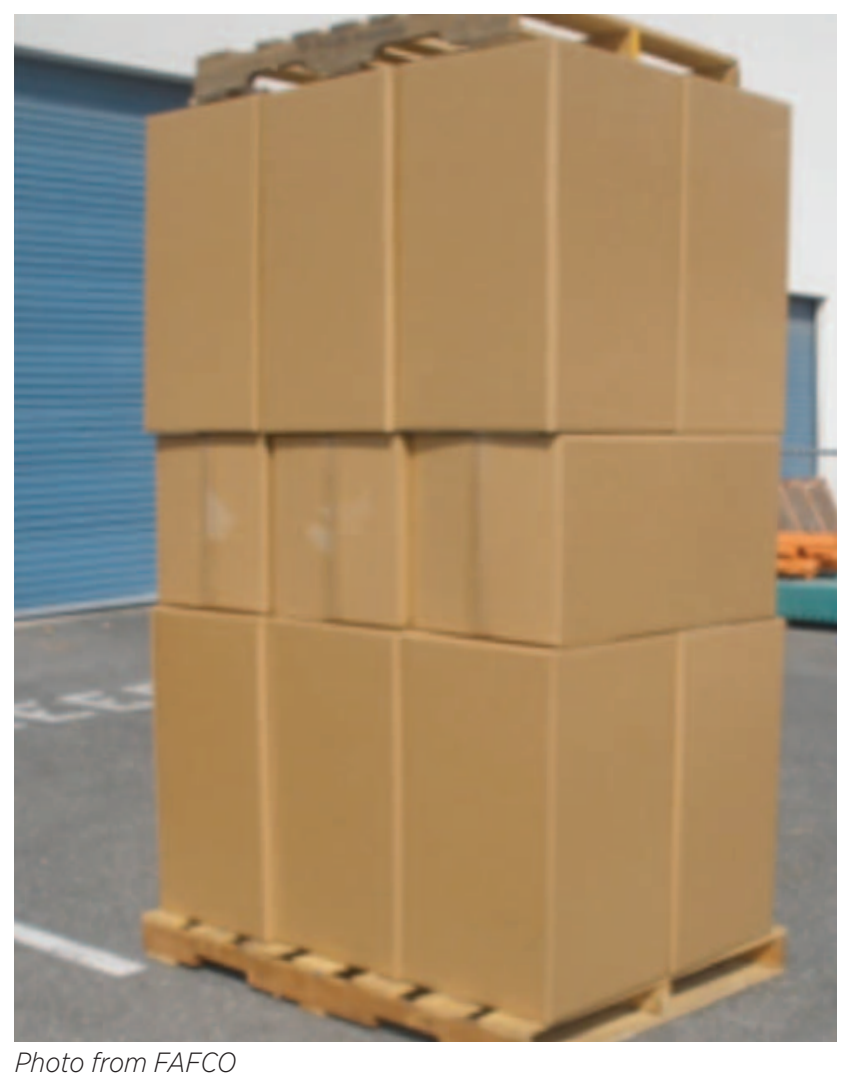

(eliminating the drainback tank). When solar energy becomes unavailable, the system pumps turn off automatically. As with the drainback system, there are two electric pumps that circulate water from the solar collectors to the heat exchanger, and from the heat exchanger to the storage.

\section{Comparative System Economics}

In this section, the economics of the two low-cost plastic systems are compared to conventional metal-glass systems, both for single-family installations and larger multi-family/ commercial systems. Solar water heater economics depend on two key factors: cost and performance/savings. Monetary savings from installing a solar water heater depend on a variety of factors, including climate, how much hot water is used, the cost of conventional fuels, and system characteristics. On average, however, the installation of a conventional packaged solar water heater for a single-family residence will decrease water heating bills by $50 \%$ to $80 \%$. The low-cost plastic packaged systems will generally achieve less savings per unit area. Savings can be increased by increasing the collector area.

Costs per square foot for collectors range from $\$ 2 / \mathrm{ft}^{2}$ for low-temperature systems used to heat pools to as high as $\$ 75 / \mathrm{ft}^{2}$ for high-temperature systems used to heat large facilities with high-volume, high-temperature water requirements. System costs range from $\$ 10 / \mathrm{ft}^{2}$ for solar pool 
Table 1. Typical Performance and Economic Metrics for Conventional and Low-cost Solar Water Heaters

\begin{tabular}{|c|c|c|c|c|c|c|c|c|c|c|c|c|c|}
\hline \multirow{3}{*}{ System/Scenario } & \multicolumn{3}{|c|}{ System Cost } & \multicolumn{4}{|c|}{ Savings 6} & \multicolumn{3}{|c|}{ Economics, no incentives } & \multicolumn{3}{|c|}{ Economics, Federal 30\% } \\
\hline & \multirow{2}{*}{$\begin{array}{c}\begin{array}{c}\text { No } \\
\text { incentives }\end{array} \\
\$\end{array}$} & \multirow{2}{*}{$\begin{array}{c}\text { No } \\
\text { incentives } \\
\$ / \mathrm{ft}^{2}\end{array}$} & \multirow{2}{*}{$\begin{array}{c}\text { w/Federal } \\
30 \% \\
\$\end{array}$} & \multirow{2}{*}{$\begin{array}{c}\text { Energy/ } \\
\mathrm{yr}\end{array}$} & \multirow{2}{*}{$\begin{array}{c}\text { Sol } \\
\text { frac } \\
-\end{array}$} & \multicolumn{2}{|c|}{ \$ Savings/yr } & \multirow{2}{*}{$\begin{array}{c}\text { Payback } \\
\text { (EI) }\end{array}$} & \multirow{2}{*}{$\begin{array}{c}\text { Payback } \\
\text { (NG) }^{8} \\
\text { Years }\end{array}$} & \multirow{2}{*}{$\begin{array}{l}\text { SWH } \\
\text { LCOE}^{9} \\
\text { cents/ } \\
\text { kWh }\end{array}$} & \multirow{2}{*}{$\begin{array}{c}\text { Payback } \\
(\mathrm{EI})^{8} \\
\text { Years }\end{array}$} & \multirow{2}{*}{$\begin{array}{c}\text { Payback } \\
\text { (NG) }^{8} \\
\text { Years }\end{array}$} & \multirow{2}{*}{$\begin{array}{c}\text { SWH } \\
\text { LCOE }^{9}\end{array}$} \\
\hline & & & & & & Elec. & $\begin{array}{l}\text { Nat. } \\
\text { Gas }\end{array}$ & & & & & & \\
\hline Conv. $40 \mathrm{ft}^{2} / \mathrm{SF}$ Retrofit 1,2 & $\$ 6,000$ & $\$ 150$ & $\$ 4,200$ & 2,509 & 0.65 & $\$ 251$ & $\$ 95$ & 24 & 63 & 15.6 & 17 & 44 & 10.9 \\
\hline Conv. $40 \mathrm{ft}^{2} / \mathrm{SF}$ Staff-installed 1,2 & $\$ 4,000$ & $\$ 100$ & $\$ 2,800$ & 2,509 & 0.65 & $\$ 251$ & $\$ 95$ & 16 & 42 & 10.4 & 11 & 29 & 7.3 \\
\hline Conv. $400 \mathrm{ft}^{2} / \mathrm{MF}$ Retrofit 2,3 & $\$ 40,000$ & $\$ 100$ & $\$ 28,000$ & 35,265 & 0.23 & $\$ 3,526$ & $\$ 1,336$ & 11 & 30 & 7.4 & 8 & 21 & 5.2 \\
\hline SunCache $32 \mathrm{ft}^{2} / \mathrm{SF}$ Retrofit ${ }^{1,4}$ & $\$ 2,500$ & $\$ 78.12$ & $\$ 1,750$ & 1,519 & 0.40 & $\$ 152$ & $\$ 58$ & 16 & 43 & 10.7 & 12 & 30 & 7.5 \\
\hline $\begin{array}{l}\text { SunCache } 32 \mathrm{ft}^{2} / \\
\text { SF Staff-installed1,4 }\end{array}$ & $\$ 1,500$ & $\$ 46.88$ & $\$ 1,050$ & 1,519 & 0.40 & $\$ 152$ & $\$ 58$ & 10 & 26 & 6.4 & 7 & 18 & 4.5 \\
\hline SunCache $320 \mathrm{ft}^{2} / \mathrm{MF}$ Retrofit & $\$ 15,000$ & $\$ 46.88$ & $\$ 10,500$ & 21,701 & 0.14 & $\$ 2,170$ & $\$ 822$ & 7 & 18 & 4.5 & 5 & 13 & 3.1 \\
\hline FAFCO $48 \mathrm{ft}^{2} / \mathrm{SF}$ Retrofit 1,5 & $\$ 3,000$ & $\$ 62.50$ & $\$ 2,100$ & 2,035 & 0.53 & $\$ 203$ & $\$ 77$ & 15 & 39 & 9.6 & 12 & 27 & 6.7 \\
\hline $\begin{array}{l}\text { FAFCO } 48 \mathrm{ft}^{2} / \mathrm{SF} \\
\text { Staff-installed }\end{array}$ & $\$ 2,000$ & $\$ 41.67$ & $\$ 1,400$ & 2,035 & 0.53 & $\$ 203$ & $\$ 77$ & 10 & 26 & 6.4 & 7 & 18 & 4.5 \\
\hline FAFCO $480 \mathrm{ft}^{2} /$ MF Retrofit 3,5 & $\$ 20,000$ & $\$ 41.67$ & $\$ 14,000$ & 36,621 & 0.24 & $\$ 3,662$ & $\$ 1,387$ & 5 & 14 & 3.6 & 4 & 10 & 2.5 \\
\hline $\begin{array}{l}\text { Assumptions: } \\
\text { 1) } 64 \text { gal/day/collector, with } 70^{\circ} \mathrm{F} \\
\text { 2) SWH retrofit: } \$ 150 / \mathrm{ft}^{2} \text {. Staff inst } \\
\text { 3) } 256 \mathrm{gal} / \text { day/collector, with } 70^{\circ} \mathrm{F} \\
\text { 4) Possible cost with efficient distr } \\
\text { 5) Possible cost with efficient distr } \\
\text { 6) Incidence: } \mathrm{Hd}=5 \mathrm{kWh} / \mathrm{m}^{2} \text {-day. } \\
\text { 7) Marginal fuel costs: i) electricity } \\
\text { 8) Payback is here defined as (Firs } \\
\text { 9) SWH system Levelized Cost of } \\
30 \text { year sylstem life). }\end{array}$ & $\begin{array}{l}\text { emperature } \\
\text { all saves } \$ 2,0 \\
\text { temperature } \\
\text { bution and } \\
\text { bution, at } \$ 6 \\
\text { Savings = Inc } \\
=0.1 \$ / \mathrm{kWh} \text {; } \\
\text { Cost)/(Ann } \\
\text { nergy (LCOE }\end{array}$ & $\begin{array}{l}\text { rise } \\
00 / \text { system } \\
\text { rise } \\
\text { nanufacturin } \\
52.50 / \mathrm{ft}^{2} \text {. Sta } \\
\text { idence*Area } \\
\text {;i) natural g } \\
\text { ual } \$ \text { savings } \\
\text { ) is defined }\end{array}$ & $\begin{array}{l}\text { (no marketin } \\
\text { g, at } \$ 75 / \mathrm{ft}^{2} \\
\text { aff install sav } \\
{ }^{*} \text { Annual syst } \\
\text { as }=1.11 / \text { the } \\
\text { s). ROI is } 1 / p \\
\text { as (First Cos }\end{array}$ & $\begin{array}{l}\text { g, low ins } \\
\text {. Staff inst } \\
\text { es } \$ 1,000 \\
\text { tem efficie } \\
\text { rm } \\
\text { ayback. Tr } \\
\text { st)/(Annua }\end{array}$ & $\begin{array}{l}\text { all cost } \\
\text { all save } \\
\text { ncy. Sy } \\
\text { ere is } n \\
\text { I kWh }\end{array}$ & $\begin{array}{l}\text {, at } \$ 100 \text {, } \\
\$ 1,000 \\
\text { tem annu } \\
\text { o account } \\
\text { avings* } \mathrm{Pr}\end{array}$ & $\begin{array}{l}\text { al effici } \\
\text { eseng of } \\
\text { esentW }\end{array}$ & $\begin{array}{l}\text { cies show } \\
M \text { costs ir } \\
\text { thFactor) }\end{array}$ & $\begin{array}{l}\text { vn in Tabl } \\
\text { n this tab } \\
\text { PWF = }\end{array}$ & 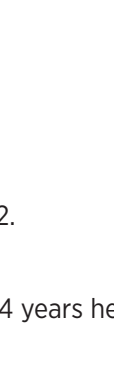 & $5 \%$ & disc & te, \\
\hline
\end{tabular}

heaters to as much as $\$ 250 / \mathrm{ft}^{2}$ for some small residential systems. New construction systems usually have better economics than retrofit projects because of reduced installation expenses. Large-scale multi-family/commercial systems have better economics than small-scale single-family systems because of better collector costs in volume and reduced balance of system per unit area. Cost also depends on whether the installation is done by an outside firm or by on-site staff that has been trained by the manufacturer. With favorable indicators on large-scale projects, low-cost systems can conceivably be installed at under $\$ 50 / \mathrm{ft}^{2}$.

Table 1 compares costs in a reasonably sunny location $\left(5 \mathrm{kWh} / \mathrm{m}^{2}\right.$-day) for conventional and two low-cost solar water heaters. Several scenarios are presented. The two single-family costs are for retrofits on single-family homes with an assumed draw of 64 gal/day (national average daily draw). The multi-family costs are for retrofits on multi-family apartments, with an assumed draw of 256 gal/day/solar-unit. Typical system costs are listed for a conventional system at 40 and $400 \mathrm{ft}^{2}$, for the SunCache at 32 and $320 \mathrm{ft}^{2}$, and the
FAFCO at 48 and $480 \mathrm{ft}^{2}$. For single family sizes, costs are given for two scenarios: i) outside contractors install turnkey systems in low volume; and ii) in-house staff-install systems. Cost is influenced by several factors extrinsic to the hardware cost, and the costs assumed here reflect assumed efficient distribution and low marketing costs, such as with a direct, high-volume order from the factory. Annual efficiency is defined as the system savings divided by the total incidence radiation (maximum savings):

$\eta_{\text {ann }}=Q_{\text {saved,ann }} / \mathrm{Q}_{\text {sol-incident }}$.

Annual efficiency provides a convenient way to summarize performance, since it is approximately constant across climates.

Table 2 lists the annual efficiencies of the systems that are typical and were assumed in estimating performance. Efficiencies are lowest for the unglazed FAFCO, and highest for the conventional glazed, selective-surface systems. Efficiencies increase at the multi-family draw loading, where the solar fraction is lower and the temperatures are cooler. 
The increase is proportionately large for the low-cost plastic systems because they have larger loss coefficients.

Without incentives, payback vs. gas fuel exceeds 30 years, except for a low-cost system in multi-family scale. Without incentives, payback vs. electric water heating exceeds 10 years, again, except for multi-family low-cost systems. The cost of saved energy $\left(\mathrm{c}_{\text {sav-enrg }}\right)$ labeled "SWH LCOE" in Table 1; the net cost of each KWh saved by the system. It is defined as

$\mathrm{c}_{\text {sav-enrg }}=($ Total costs $) /($ Total Discounted Fuel Savings $)$

where:

Total Discounted Fuel Savings $=$ PWF ${ }^{*}$ Qfuel-savings/year , and $\mathrm{PWF}=$ Present Worth Factor.

Displacing fuel on the margin, this compares directly to the marginal cost of conventional fuel. The cost of maintenance will be very small for the SunCache ( $<1 \%$ of savings) and comparable to conventional systems for the FAFCO (of order $2 \%$ savings). Maintenance cost is ignored in the analysis here. $\mathrm{C}_{\text {sav-enrg }}$ is independent of the cost of auxiliary fuel, whereas simple payback depends inversely on the cost of fuel.

The system cost analyses here are reasonably typical, but performance will depend on many factors, including local site irradiance, site draw volume and patterns, and local shading, to name a few. Fortunately, it will be possible to perform site-specific results via state-of-the-art simulations, thanks to a web site provided by the CSI. The site provides performance rating calculations for 24 system configurations and user-specified loads, orientation, and shading. A web site that will have links to the calculator when it is posted is energycenter.org/index.php/incentive-programs/solar-waterheating. These models will also be imbedded in a stand-alone simulation called Systems Advisor Model that allows more design flexibility for both residential and commercial-scale systems. Rollout is expected in early 2012, and descriptions and download instructions can be found at www.nrel.gov/ analysis/sam/.

\section{System Design Considerations}

In this section, typical design considerations as found in many references are considered in relation to the low-cost systems.

\section{Target Lower Solar Fractions}

Conventional solar water heating systems are often designed to minimize life-cycle costs by producing $100 \%$ of the load on the sunniest day of the year, and then using more backup energy (electric or fuel) during winter. Such a system will usually produce about $60 \%$ to $80 \%$ of the annual load. Usually, it is not recommended to design for $100 \%$ of the entire load because the much-larger collector size and storage tank requirements do not make it cost effective and overheating (thus wasted energy) occurs often in summer. Also, utility rebate programs may impose additional design requirements. For example, a solar water heating system must meet $90 \%$ of the load in order to qualify for Hawaiian Electric Company rebates. The new plastic packaged solar water heating systems, on the other hand, are designed to meet a lower fraction of the load since they are inefficient at higher temperatures and will deliver less useful heat at higher temperatures. It should be easier, however, to meet the 30\% statutory goal with these low cost systems, because at those low solar fractions, operation is mostly at lower temperatures where the low-cost systems are comparably efficient to conventional systems. See Table 2 for typical efficiency at low and high loads.

Table 2. Typical Annual Efficiencies

\begin{tabular}{|l|c|c|c|}
\hline \multicolumn{4}{|c|}{ Annual System Efficiencies } \\
\hline & Conventional & SunCache & Revolution \\
\hline $64 \mathrm{gal} / \mathrm{day} / \mathrm{coll}$ & 0.37 & 0.28 & 0.20 \\
\hline $256 \mathrm{gal} /$ day/coll & 0.52 & 0.47 & 0.36 \\
\hline
\end{tabular}

\section{Do Not Use Mounting Racks}

Solar collectors should generally be oriented toward the equator at a tilt equal to the local latitude to optimize performance. However, good performance can be achieved with considerable deviation from that optimal orientation. For maximum performance in the continental United States, collectors should be rotated within $30^{\circ}$ of true (not magnetic) south. Also, the tilt of the collecting array should be optimized. Surfaces tilted up from the horizontal at an angle of latitude minus $15^{\circ}$ maximize summer solar gains but reduce winter gains. Surfaces tilted up at latitude plus $15^{\circ}$ maximize winter solar gains and result in a solar delivery that is uniform throughout the year. A tilt angle equal to the local latitude maximizes year-round solar gains and optimizes for solar water heaters facing south. With conventional solar collectors, racks allow for almost any tilt angle. Low-cost plastic packaged solar water heating systems, on the other hand, are most often flush on a pitched roof in order to uniformly support the flexible plastic collectors; this orientation reduces installation costs and improves aesthetics. In any case, the performance falls off very slowly for "off optimum" orientation.

\section{Maintain Systems}

All systems require periodic maintenance. The owner's manual will have guidelines for maintenance. In general, owners should frequently check the preheat tank temperature (it should be hot after a sunny day) and once a year inspect 
the system for any physical damage to collectors or pipe insulation; check that temperature sensors are accurate and still connected properly; check pump for proper starting and operation; and check heat transfer fluid for $\mathrm{pH}$ and freeze protection. Every 10 years or so the heat transfer fluid will need to be flushed and replaced. Repair any defects so that the life cycle cost savings of the system may be realized.

It is possible to definitively check overall operation against design specifications by taking tank temperature data over several sunny days. Sensors can be installed on the side of the tank. Total solar gain is inferred from the rise in tank temperature. Depending on the stratification during charge, one to three temperature sensors are used. The ratio of energy delivered to energy expected on a clear day, start/stop times on the pump, and tank loss coefficient are inferred from the data. The method is detailed in Diagnosis of Solar Water Heaters published by NREL (see Appendix A: Resources). The method was used for several field trials with low-cost systems.

The low-cost plastic systems have several specific needs. The SunCache collector must be checked for appropriate water level every four years. This is to assure that a leak has not developed, and to make up for loss of water that will very slowly permeate as vapor through the plastic wall. The FAFCO Series 200 system is an open-to-atmosphere drainback system, and the water level in the drainback should be checked annually and refilled as necessary. The FAFCO Series 500 systems are glycol systems. It is usually recommended that glycol be changed out every five years in conventional systems. The glycol in the Series 500 will last longer because of its relatively low operating temperature, and should be checked every 10 years.

\section{Choose Systems with Load and Cimate in Mind}

Selecting the right solar water heating system for a Federal facility depends on three key factors: climate, budget, and water usage needs. Solar water heating systems are economical, especially in buildings where the energy used to heat water is significant. Table 3 gives a brief overview of systems that work best in warm and cold climates as well as systems that are best for different building sizes. Hard water tolerance is also considered. The low-cost plastic systems are explicitly called out. In addition, reliable off-the-shelf systems can be selected from the Directory of the Solar Rating and Certification Corporation at www.srcc.org.

Freeze tolerance is a key attribute in system selection. Water freezing in the collector flow passages or connecting piping can damage the system. Conventional glycol systems prevent freeze damage by circulating a solution of propylene glycol (never use toxic ethylene glycol) and water in the collector loop of an indirect system. Another strategy is to drain the water from the collector back into a small drainback tank. This drainback configuration has the added advantage of protecting the system's heat transfer fluid from excessive temperatures if hot water consumption is reduced by seasonal use patterns, remodeling, or vacations. For freeze reasons, the SunCache system should be installed in warmer climates only. As a drainback, the FAFCO system can be installed in any climate. However, note that the system will

Table 3. System Selection Guide Based on Climate, Building Size, and Maintenance

\begin{tabular}{|l|l|l|l|l|}
\hline Passive Systems (Warmer Climates) & Building Type & Freeze Tolerance & Hard Water Tolerance & Maintenance \\
\hline Direct ICS or batch & Small to medium & Moderate $\left(12^{\circ} \mathrm{F}\right)$ & Good & Very low \\
\hline Indirect ICS (SunCache) & Small to medium & Moderate (9 F) & Moderate & Very low \\
\hline Direct Thermosiphon & Small & Poor & Poor & Low \\
\hline Indirect Thermosiphon & Small & Moderate to good & Good & Low \\
\hline Active Systems (Colder Climates) & Building Type & Freeze Tolerance & Hard Water Tolerance & Maintenance \\
\hline Draindown and recirculating & Small & Poor & Poor & High \\
\hline Flat-plate/glycol-glazed & Small to large & Excellent & Moderate to good & Moderate \\
\hline Flat-plate/glycol-unglazed (FAFCO Series 500) & Small to large & Excellent & Excellent & Moderate \\
\hline Flat-plate/drainback-glazed & Small to large & Excellent & Moderate to good & Low \\
\hline Flat-plate/drainback-unglazed (FAFCO Series 200) & Small to large & Excellent & Excellent & Low \\
\hline Evacuated tube & Small to large & Good to excellent & Moderate to good & Low to moderate \\
\hline Parabolic trough & Large & Good & Good & High \\
\hline
\end{tabular}


deliver diminished energy in cold climates during winter, relative to glazed collectors; if winter delivery is important, choose a glazed system.

\section{Applications}

Heating water with solar energy can reduce conventional energy use at any Federal facility, while commercial facilities with high hot water demands and access to a good southern exposure can be great candidates. Restaurants, bakeries, beauty salons, health clubs, and hotels are all potentially good sites. A commercial installation generally makes use of the same system design and components as residential systems, including a conventional back-up for hot water heating during high-load and low-sun periods. The low-cost systems are particularly applicable to large-scale systems at lower solar fractions, because they perform most efficiently (and comparable to conventional systems) at low collector temperatures.

\section{Small Facilities}

Smaller facilities can benefit from passive solar water heating technologies and low-cost plastic packaged systems. These systems are less costly and require less maintenance than active systems. Systems that operate passively without pumps or electronic controls are often appropriate in warmer climates. In cold climates, at least today, only active systems can be installed.

\section{Large Facilities}

Large facilities such as prisons, hospitals, and military bases with consistent need for large volumes of hot water can also use solar water heating technologies cost effectively. Active

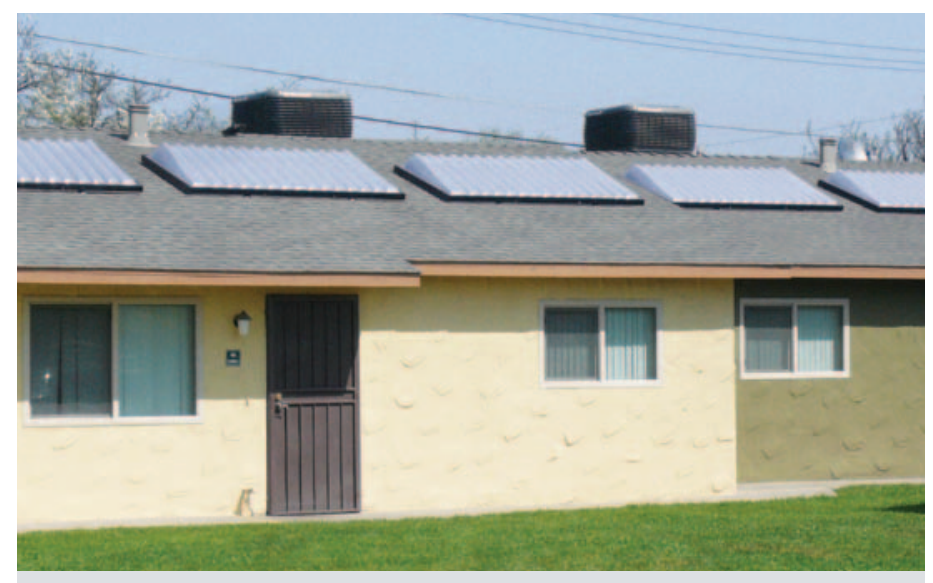

Fig. 11. Forty SunCache collectors were installed in three separate systems at an apartment complex in Hanford, California. Each system uses parallel pre-heating arrays ranging from 11 to 15 collectors, pre-heating pairs of high efficiency commercial gas water heaters. The entire project took less than 100 man-hours to install. Photo from Harpiris Energy

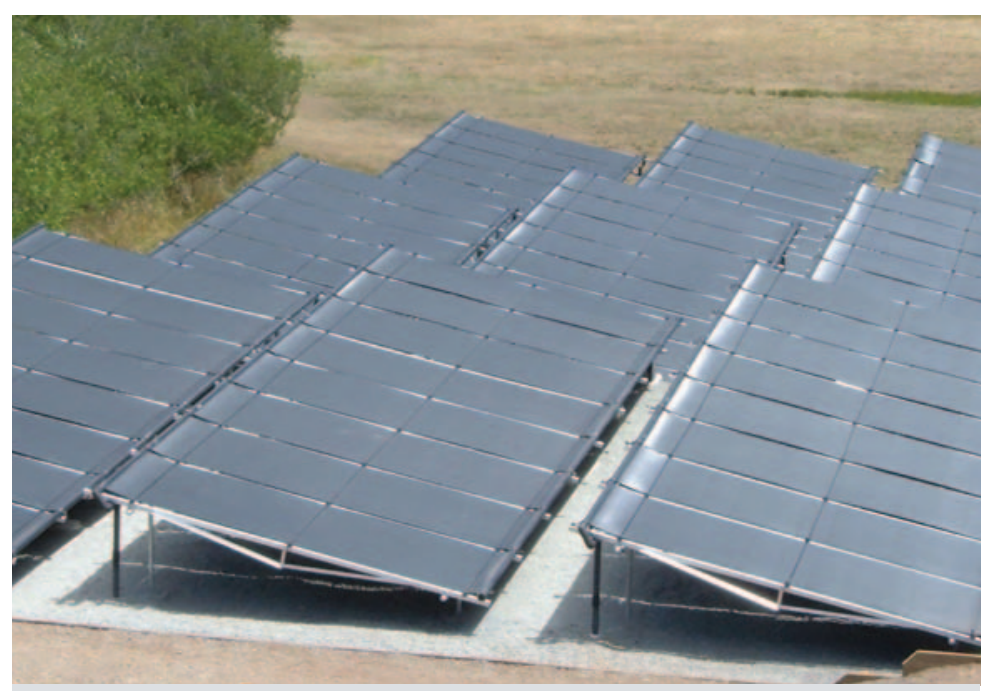

Fig. 12. FAFCO commercial system collector array in California. Photo from FAFCO

indirect systems work well for large facilities; however, for facilities with high water and high temperature volume needs, such as laundries, evacuated tube and parabolic trough systems are especially attractive because they can meet the high temperature demands while the economies of scale keep costs down to competitive levels. Low-cost plastic packaged systems come in designs to serve small loads, but can be linked in parallel to preheat water for large loads as well, especially at a lower solar fraction where the systems run relatively cool.

\section{Swimming Pools}

Facilities with swimming pools are also good candidates for plastic solar collectors because of the lower heating requirements to provide comfortable water temperatures.. Pool systems will often pay for themselves in just a few years, particularly for pools that are used year round. Relatively inexpensive low-temperature systems are quite effective and can either greatly reduce conventional pool heating bills or extend the season where heating was considered too expensive.

\section{Financing}

Financing is available for solar hot water systems for Federal facilities. Among the alternative financing methods available are Energy Savings Performance Contracting (ESPC) and utility programs including:

- DOE's Federal Energy Management Program (FEMP) has established an Indefinite Quantity Contract (IQC) under which any Federal agency can issue Delivery Orders for solar water heating systems in an ESPC arrangement. For more information, visit www.eere.energy.gov/femp/ financing/mechanisms.html. 
- Several utilities offer rebates, leases, or other solar water heating programs. A complete listing of incentives is provided in the Database of State Incentives for Renewable Energy at www.dsireusa.org.

In general, low-cost systems should present a cost advantage, especially when targeting lower solar fractions.

\section{Software}

NREL developed the Federal Renewable Energy Screening Assistant (FRESA) software that can help facility managers determine if their building is a possible candidate for a solar water heating system. This Windows-based software tool screens Federal renewable energy projects for economic feasibility and evaluates renewable technologies including solar water heating systems, photovoltaic, and wind energy systems. The Federal Energy Management Program (FEMP) is developing a new version, but information about the current version is available at: $h t t p s: / / w w w 3$.eere.energy.gov/ femp/fresa/.

A somewhat more detailed screening tool is provided by the Canadian Retscreen at www.retscreen.net/. In addition, the following software programs provide a more detailed engineering and economic analysis

- SAM, software available from NREL at www.nrel.gov/ analysis/sam/

- FCHART, correlation method, available from the University of Wisconsin at sel.me.wisc.edu/fchart/new_ fchart.htm/

- TRNSYS, software, available from the University of Wisconsin at sel.me.wisc.edu/trnsys/.

The FEMP Help Line (800-DOE-EREC) provides manuals and software for detailed economic evaluation and for the Energy Savings Performance Contracting Program that allows Federal facilities to repay contractors for solar water heating systems through bills for energy savings instead of paying for initial construction.

\section{Water Conservation}

To reduce water heating bills and solar water heating system size, consider using conservation methods such as low-flow shower heads, faucet aerators, optical sensor faucets, water saving clothes washers and dishwashers, water heater insulation, hot-water piping insulation, timed water heaters, on-demand recirculation systems, and swimming pool covers. NREL-developed software screens facilities for water conservation opportunities. For more information, visit www.eere.energy.gov/femp/program/waterefficiency resources.html. 


\section{Solar Resource}

Solar water heating systems work well in all climates. However, some systems are better suited for warm climates while others work well in cold climates. In general, facilities located in colder climates will need to purchase a system with good freeze protection. Facilities located in warmer climates can use most passive systems. The solar radiation map shows sunny areas in red, orange, and yellow. Facilities located in the blue/green areas have less sunlight available.

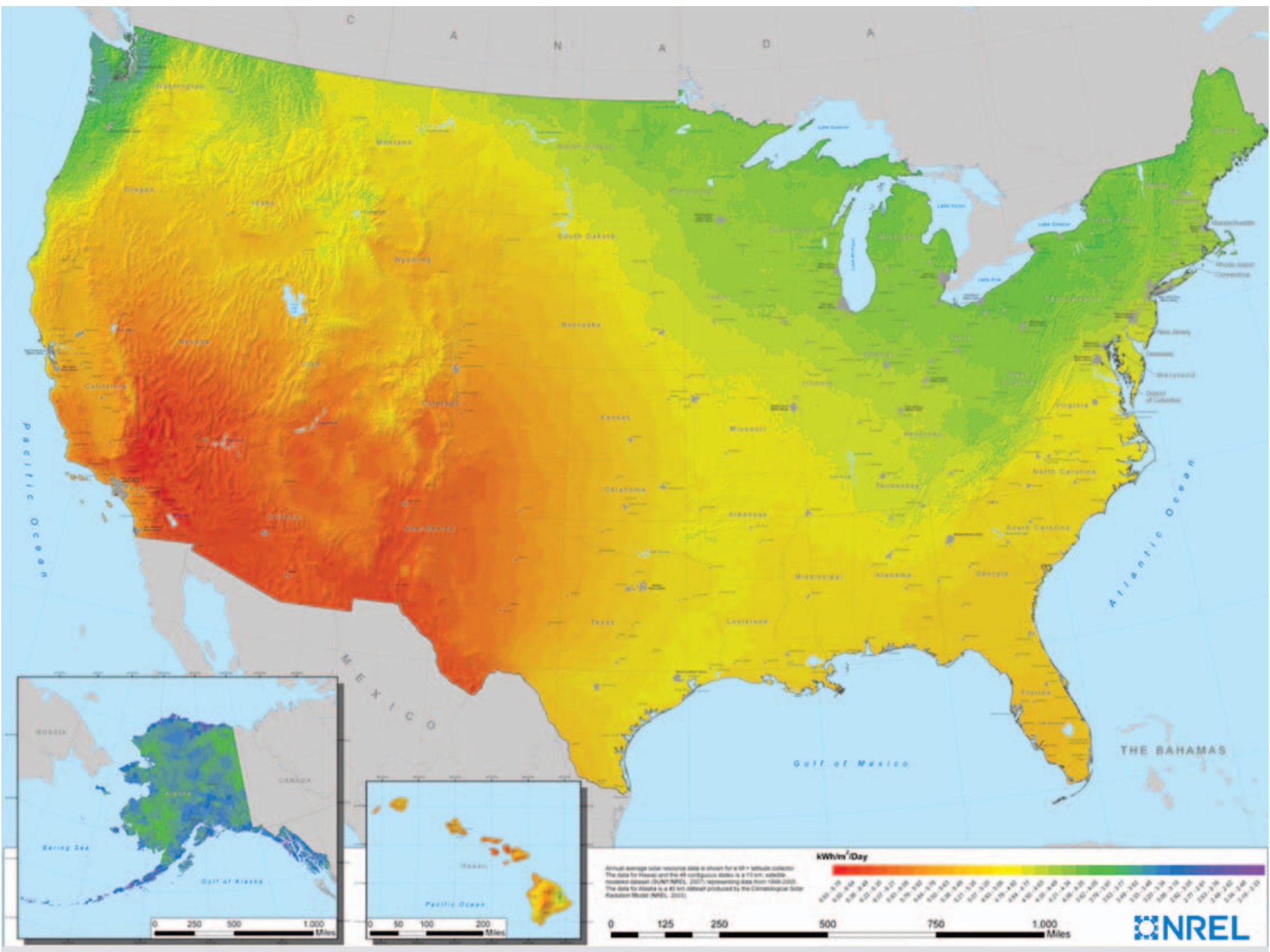

Fig. 13. Solar resource for the continental U.S., Hawaii, and Alaska in kWh/m²/day. Illustration by Donna Heimiller, NREL 


\section{Appendix A: Resources}

Numerous resources are available for more information about solar water heating technologies.

\section{Economics}

\section{Solar Estimate}

A free public service offering solar estimating tools supported by the U.S. Department of Energy and the California Energy Commission.

wWw.solar-estimate.org

\section{Solar Water Heater Online Calculator}

Infinite Power is a nonprofit organization that provides an online calculator to estimate system size and cost savings for residential scale systems. www.infinitepower.org/calc_waterheating.htm

\section{Federal Codes, Standards, and Regulations}

Federal Energy Management Program

Federal agencies must meet energy management requirements described on this site.

www.eere.energy.gov/femp/regulations/requirements_by subject.html

\section{National Institute of Building Sciences}

Maintains a list of Executive Orders (EO) associated with building design, construction, and management. EOs related to reducing energy consumption through renewable energy sources such as solar water heating are discussed in EOs 13514 (2009), 13423, 13123 and 12902. www.wbdg.org/references/exec_orders.php

\section{North Carolina Solar Center}

Maintains a database of state incentives for renewables and energy efficiency, but it also tracks Federal standards and regulations. Visit "Federal Incentives" at the Web site below, then scroll to the bottom of the page for a list of energy standards for public buildings.

www.dsireusa.org/incentives

\section{Manufacturers}

The Solar Rating and Certification Program has a searchable company database on its Web site: www.solar-rating.org/ certification/companies.html. The Solar Energy Industries Association (SEIA) maintains an up-to-date list of member manufacturers. Search for solar companies by name or by terms such as "solar water heating" or "plastic collector" to find companies that deal with specific areas of interest to your facility. Look for the blue SEIA Solar Directory search box on the homepage at www.seia.org.
Below is contact information for the two solar companies featured in this document.

\section{FAFCO}

FAFCO Incorporated

435 Otterson Drive

Chico, CA 95928

Phone: (800) 994-7652

www.fafco.com

\section{SunCache}

Harpiris Energy

25205 Baronet Road

Corral de Tierra, CA 93908

Phone: 530-220-7000

www.harpiris.com

Organizations, Associations, and Government Agencies

\section{American Solar Energy Society}

Nonprofit organization that provides information to consumers and the industry about solar energy. Www.ases.org

\section{Florida Solar Energy Center}

Provides professionals and consumers with information and ratings of solar water heating systems. www.fsec.ucf.edu/en/

\section{National Renewable Energy Laboratory}

Conducts solar water heating research for the U.S.

Department of Energy. www.nrel.gov

\section{Solar Energy Industries Association}

Trade organization for solar industry that includes fact sheets and guides as well as information about policies affecting solar water heating. www.seia.org/cs/solar_thermal_heating_cooling

\section{U.S. Department of Energy}

The DOE Office of Energy Efficiency and Renewable Energy provides consumer guides for purchasing solar water heating systems. Www.eere.energy.gov

\section{Solar Water Heating - General Information}

J. Burch et. al. Diagnosis of Solar Water Heaters Using Solar Storage TankSurface Temperature Data. Paper presented at the American Solar Energy Society (ASES) 2009 National Solar Conference (SOLAR 2009, Buffalo, New York, May 11-16, 2009. www.nrel.gov/docs/fy09osti/45465.pdf

J. Burch et.al. Pipe Freeze Prevention for Passive Solar Water Heaters Using a Room-Air Natural Convection Loop. Paper presented at Solar 2006. www.nrel.gov/docs/fy06osti/39722.pdf

U.S. Department of Energy www.eere.energy.gov/topics/solar.html 


\section{System Ratings and Certifications}

\section{Florida Solar Energy Center}

The Florida Solar Energy Center maintains a list of ratings for solar water heating systems. www.fsec.ucf.edu/en/ certification-testing/STcollectors/index.htm

\section{Solar Rating and Certification Corporation (SRCC)}

SRCC is a nonprofit organization that rates and certifies solar energy equipment. www.solar-rating.org

\section{SRCC Guidelines for Commercial Buildings}

SRCC provides information about installation and maintenance for commercial solar water heating systems. www.solar-rating.org/commercial/index.html 


\section{Appendix B: SRCC OG300 Rating for SunCache and FAFCO}

Below are the SRCC rating pages for SunCache and FAFCO systems. The SRCC provides detailed data on its Web site for cost and efficiency comparison using the SRCC rating pages at: www.solar-rating.org/ratings/index.htm/. Though not shown here, the SRCC Website also generates estimated electricity savings for systems with SRCC certification (go to www.solar-rating.org/ ratings/ratings.htm and select Certified Systems and Ratings) based on the system and location. The electricity savings can be used to estimate reductions in GHG emissions using the EPA Power Profiler www.epa.gov/cleanenergy/energy-and-you/howclean.html, or Federal agencies can enter the annual electricity savings from SRCC into the Annual GHG and Sustainability Data Report (www.fedcenter.gov/Documents/index.cfm?id=16387) along with their facility zip code to see how much greenhouse gas is emitted by the electricity saved by a solar water heater installed at one of their buildings.

\section{CERTIFIED SOLAR WATER HEATING SYSTEM}

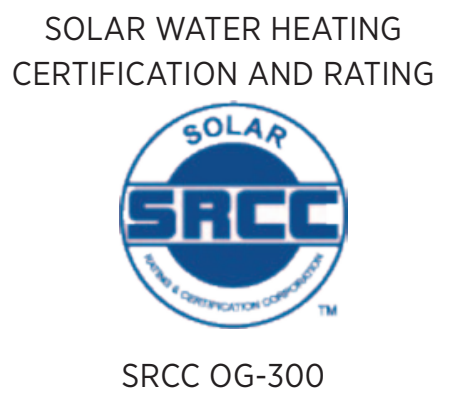

SUPPLIER:

Fafco, Inc.
435 Otterson Dr.
Chico, CA 95928 USA
(530) 332-2100
(530) 322-2109 Fax
(800) 994-7652

SYSTEM NAME: Polymer Drainback

SYSTEM TYPE: Indirect Forced Circulation

LOCATION: Select Location

Description: Unglazed Flat-Plate, Differential Controller, Plate Heat Exchanger with a Single Wall, No Load Side Heat Exchanger, Freeze Tolerance: $-20^{\circ} \mathrm{F}$, Fluid Class I, Electric Auxiliary Tank

\begin{tabular}{|c|c|c|c|c|c|c|c|c|c|c|c|}
\hline $\begin{array}{l}\text { System } \\
\text { Model_name }\end{array}$ & Cert 300\# & Cert Date & $\begin{array}{c}\text { Collector } \\
\text { Panel } \\
\text { Manufacturer }\end{array}$ & $\begin{array}{c}\text { Collector } \\
\text { Panel Name }\end{array}$ & $\begin{array}{c}\text { Total } \\
\text { Panel area } \\
(\text { Sq-m) }\end{array}$ & $\begin{array}{c}\text { Total } \\
\text { Panel area } \\
\text { (Sq-ft) }\end{array}$ & $\begin{array}{l}\text { Solar } \\
\text { Tank } \\
\text { Vol(I) }\end{array}$ & $\begin{array}{c}\text { Solar } \\
\text { Tank } \\
\text { Vol(g) }\end{array}$ & $\begin{array}{c}\text { Aux } \\
\text { Tank } \\
\text { Vol(l) }\end{array}$ & $\begin{array}{c}\text { Aux } \\
\text { Tank } \\
\text { Vol(g) }\end{array}$ & SEF \\
\hline $\begin{array}{l}\text { VDB- } \\
24 U \times 2-80 E\end{array}$ & $2007002 \mathrm{~K}$ & 09-JUL-09 & Fafco, Inc. & Sungrabber & 4.5 & 48.8 & & & 303 & 80 & 1.7 \\
\hline $\begin{array}{l}\text { VDB- } \\
48 U \times 2-50 E\end{array}$ & $2007002 C$ & 03-APR-07 & Fafco, Inc. & Revolution & 8.8 & 94.9 & & & 189 & 50 & 2.4 \\
\hline $\begin{array}{l}\text { VDB- } \\
48 U \times 2-80 E\end{array}$ & 2007002D & 03-APR-07 & Fafco, Inc. & Revolution & 8.8 & 94.9 & & & 303 & 80 & 2.3 \\
\hline $\begin{array}{l}\text { VDB- } \\
48 U \times 2-120 E\end{array}$ & $2007002 F$ & 16-JUN-09 & Fafco, Inc. & Revolution & 8.8 & 94.9 & & & 454 & 120 & 2.2 \\
\hline $\begin{array}{l}\text { VDB- } \\
24 U \times 2-50 E\end{array}$ & $2007002 \mathrm{~J}$ & 09-JUL-09 & Fafco, Inc. & Sungrabber & 4.5 & 48.8 & & & 189 & 50 & 1.7 \\
\hline $\begin{array}{l}\text { VDB- } \\
24 U \times 2-120 E\end{array}$ & $2007002 \mathrm{~L}$ & 09-JUL-09 & Fafco, Inc. & Sungrabber & 4.5 & 48.8 & & & 454 & 120 & 1.6 \\
\hline
\end{tabular}




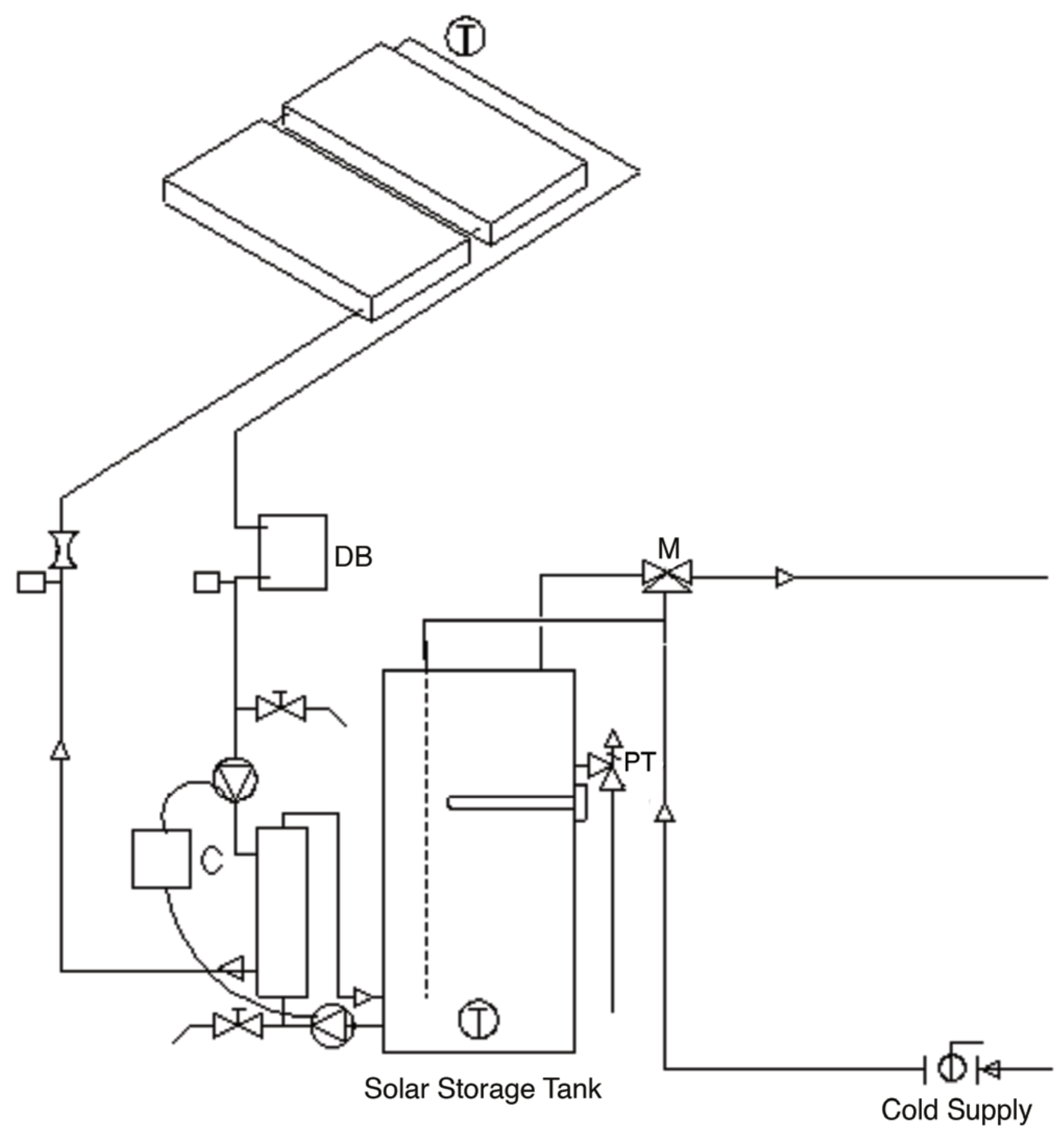

OG-300 System Reference: 2007002C SVG Diagram Display 


\section{CERTIFIED SOLAR WATER HEATING SYSTEM}

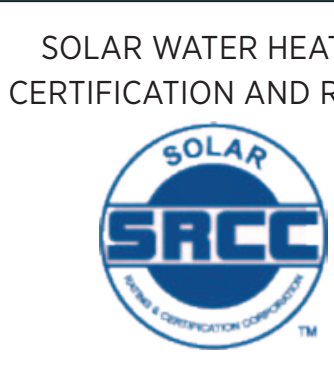

SRCC OG-300
SUPPLIER: Harpiris Energy, LLC

25205 Baronet Road

Corral de Tierra, CA 93908 USA

(530) 564-1100

(530) 564-1100 Fax

SYSTEM NAME: SunCache

SYSTEM TYPE: Indirect Integral Collector Storage

LOCATION: Select Location

Description: No Controller, No Supply Side Heat Exchanger, Immersed Coil Heat Exchanger with a Single Wall, Freeze Tolerance: 20 F, Fluid Class I, Electric Auxiliary Tank Certification is based on a System Test.

\section{System}

Model_name

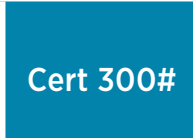

SCG-50-ES
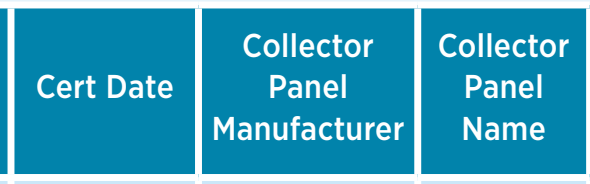

Total
Panel area
$(\mathrm{Sq}-\mathrm{m})$

Total
Panel area
(Sq-ft)

\begin{tabular}{|l} 
Solar \\
Tank \\
Vol(I) \\
\hline \\
\hline
\end{tabular}

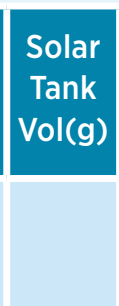

Tank

Vol(I)

3.2
Aux

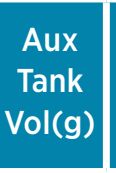

189 


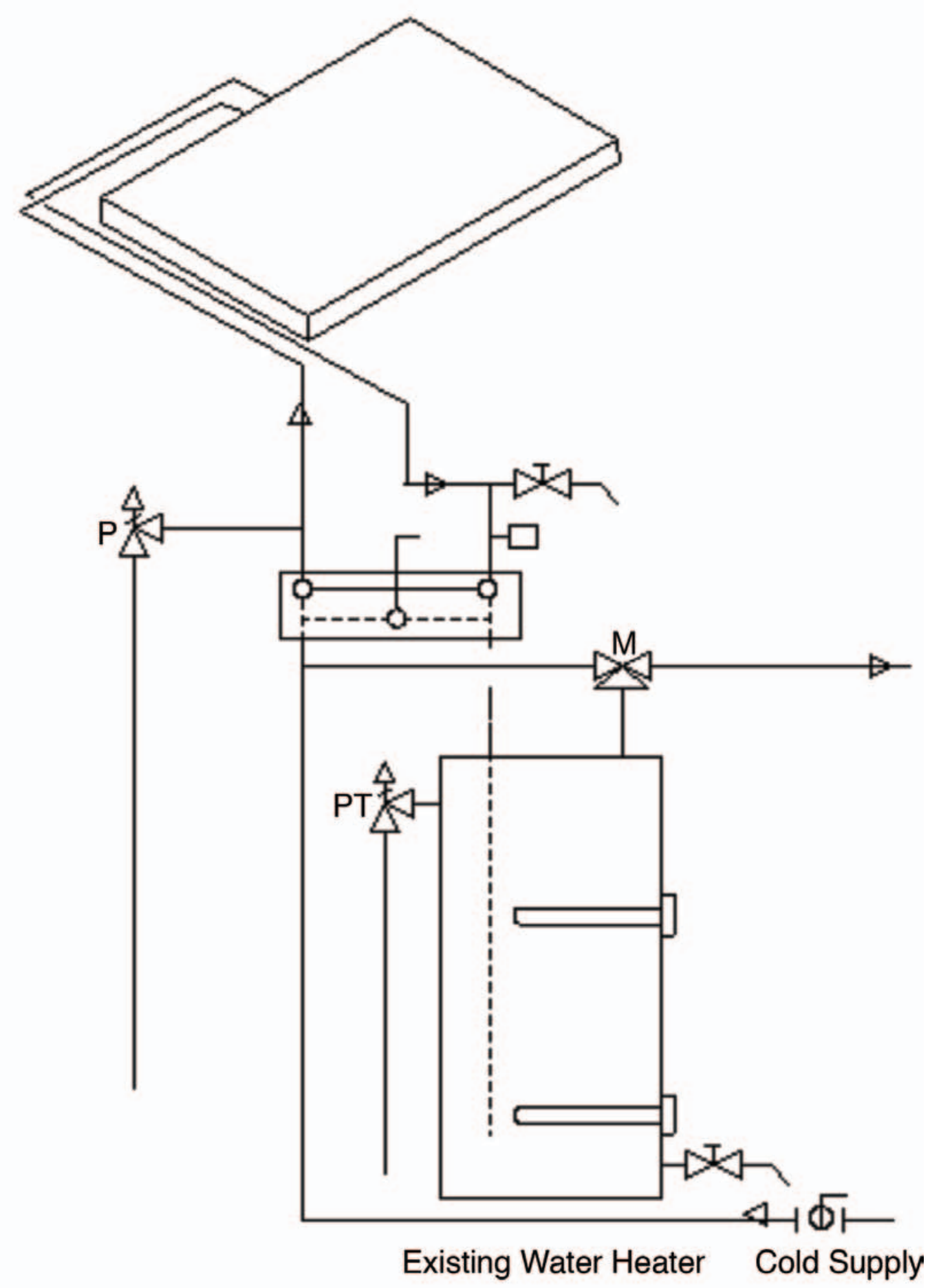

OG-300 System Reference: 2009005A SVG Diagram Display 
